\title{
Carbohydrate-Based Azacrown Ethers in Asymmetric Syntheses
}

\author{
István Orbán, Péter Bakó and Zsolt Rapi *(1) \\ Department of Organic Chemistry and Technology, Budapest University of Technology and Economics, \\ 1111 Budapest, Hungary; istvan.orban94@gmail.com (I.O.); bako.peter@vbk.bme.hu (P.B.) \\ * Correspondence: rapi.zsolt@vbk.bme.hu
}

check for updates

Citation: Orbán, I.; Bakó, P.; Rapi, Z. Carbohydrate-Based Azacrown Ethers in Asymmetric Syntheses. Chemistry 2021, 3, 550-577. https:/ / doi.org/10.3390/chemistry3020039

Academic Editors: Edwin

Charles Constable, György Keglevich, Réka Henyecz and Rádai Zita

Received: 28 February 2021

Accepted: 12 April 2021

Published: 15 April 2021

Publisher's Note: MDPI stays neutral with regard to jurisdictional claims in published maps and institutional affiliations.

\begin{abstract}
Carbohydrate-based crown ethers represent a special group of chiral phase transfer catalysts. Several derivatives of these macrocycles have been synthesized in our research group. Among these compounds, monoaza-15-crown-5 lariat ethers proved to be effective phase transfer and enantioselective catalysts in certain reactions. Those chiral azacrown ethers incorporating various carbohydrate moieties in the macrocyclic structure are reviewed, which generated asymmetric induction in reactions, such as Michael addition, epoxidation of enones, Darzens condensation and Michael-initiated ring-closure (MIRC) reaction. Effects on the catalytic activity of the structural changes are the focus.
\end{abstract}

Keywords: crown ether; carbohydrates; enantioselectivity; asymmetric synthesis

\section{Introduction}

The modern and most economical method of preparing enantiopure compounds is asymmetric synthesis carried out in the presence of chiral catalysts or auxiliaries. An enormous number of catalysts have been prepared worldwide to replace the most commonly applied techniques, i.e., resolution of racemic mixtures. Chiral crown ethers represent a special type of chiral catalysts, which can generate asymmetric induction as phase transfer catalysts. The first chiral crown ethers were synthesized by Cram and co-workers using BINOL as the source of chirality, which proved to be effective as enantioselective catalysts in phase transfer reactions [1].

Phase transfer catalysis has been recognized as one of the most useful synthetic tools in organic chemistry offering several advantages, such as operational simplicity, mild reaction conditions, inexpensiveness and less harmful reagents and solvents. This research field has been serving as an attractive area of green chemistry as well. Asymmetric phase transfer catalysis, particularly over the past two decades or more, has become a topic of great scientific interest, and as a result of the efforts, many highly efficient enantioselective catalysts have been developed [2,3].

It seemed advantageous to use carbohydrates for the synthesis of crown ethers. Sugars are a suitable source of chirality, are commercially available in enantiomerically pure form and are well-endowed with functionality.

Although several chiral crown ethers have been prepared from carbohydrates earlier, only a few of them showed (at least) moderate asymmetric induction as catalysts in asymmetric reactions [4-8]. Our research group, as a pioneer in this field, started developing new carbohydrate-based crown ethers and tested these compounds as catalysts in enantioselective reactions. A variety of chiral crown ethers containing one or two sugar units in annulation with the macrocyclic ring from various monosaccharides and sugar alcohols were synthesized in our laboratory. These compounds generated significant asymmetric induction when used as chiral phase transfer catalysts in different reactions.

Some carbohydrate-based azacrown ethers have also been prepared by other European research groups. Diaza macrocycles derived from mannose (1a-d), glucose (2a-d) and galactose (3a-d), were synthesized by Polish researchers in 1984 [9]. Application as catalysts or investigation of crown compounds 1-3 have not been reported to date. 


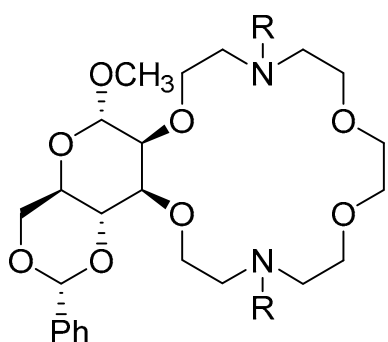

1a $\mathrm{R}=\mathrm{H}$

1b $\mathrm{R}=\mathrm{CH}_{3}$

1c $\mathrm{R}=\mathrm{SO}_{2} \mathrm{C}_{6} \mathrm{H}_{4} \mathrm{CH}_{3}$

$1 d \mathrm{R}=\mathrm{COOC}_{2} \mathrm{H}_{5}$<smiles>[R]N1CCOCCOCCN([R])O[C@H]2[C@@H](OCC1)[C@@H](OC)[C@H](OC)O[C@@H]1CO[C@H](c3ccccc3)O[C@@H]21</smiles>

2a $\mathrm{R}=\mathrm{H}$

2b $\mathrm{R}=\mathrm{CH}_{3}$

2c R $=\mathrm{SO}_{2} \mathrm{C}_{6} \mathrm{H}_{4} \mathrm{CH}_{3}$

2d R $=\mathrm{COOC}_{2} \mathrm{H}_{5}$<smiles>[R]N1CCOCCOCCN([R])O[C@@H]2[C@H]3O[C@@H](c4ccccc4)OC[C@H]3O[C@H](OC)[C@@H]2OCC1</smiles>

3a $\mathrm{R}=\mathrm{H}$

3b $\mathrm{R}=\mathrm{CH}_{3}$

$3 \mathrm{c} \mathrm{R}=\mathrm{SO}_{2} \mathrm{C}_{6} \mathrm{H}_{4} \mathrm{CH}_{3}$

$3 \mathbf{d} \mathrm{R}=\mathrm{COOC}_{2} \mathrm{H}_{5}$

Jarosz and Lewandowski developed the synthesis of macrocyclic compounds from sucrose (a disaccharide). Among others, azacrown ethers $\mathbf{4} \mathbf{a}-\mathbf{b}$ and $\mathbf{5}$ containing sucrose as the chiral base were synthesized [10]. Investigating the complexing properties, enhanced ability was determined towards $\mathrm{NH}_{4}{ }^{+}$ions, especially in the case of $4 \mathbf{b}$ and 5 .<smiles>BrCc1ccccc1</smiles>

$4 a \mathrm{a}=\mathrm{O}$ $\mathbf{4 b} \mathrm{Q}=\mathrm{NBn}$

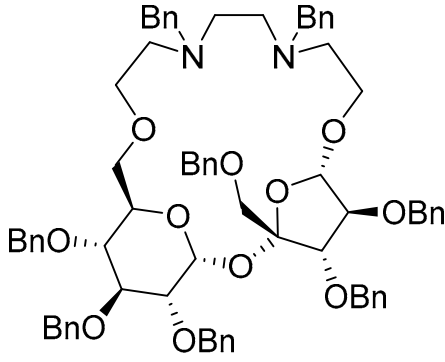

5

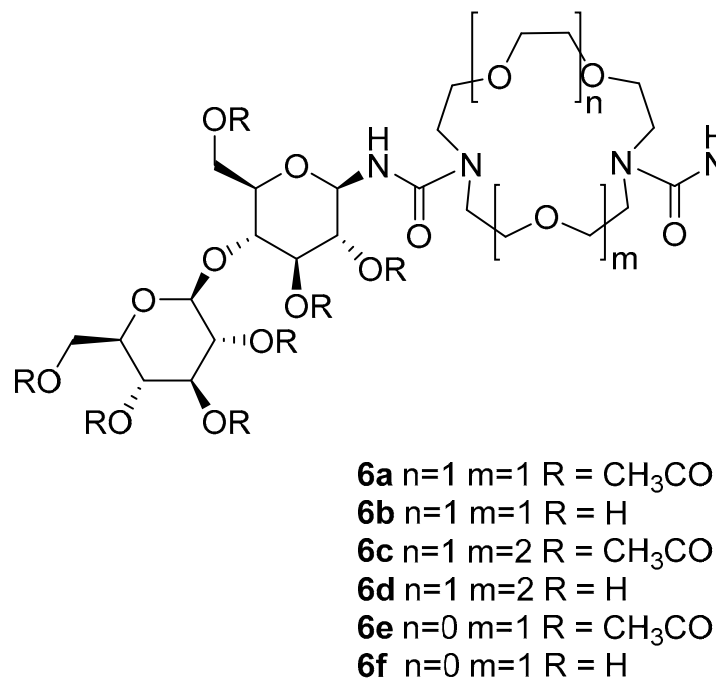

Another disaccharide was used to build up chiral crown derivatives by Porwanski et al. Diaza macrocycles bearing two cellobiose units $\mathbf{6 a - f}$ were investigated in complexation of busulfan, lysine, arginine [11], acetylsalicylic acid, 4-acetamidophenol [12] and tosylamide [13]. Quantum chemical calculations were also applied to the complex of $\mathbf{6 b}$ with aspirin [14].

Rhatjens and Thiem published several azamacrocycles containing the nitrogen atoms as tosylamide units. First, starting from glucose, crown ethers, e.g., $\mathbf{7}$ and $\mathbf{8 a}-\mathbf{b}$, with 
larger rings in annulation of two monosaccharide moieties were prepared [15]. While in compounds 7 and 8 , the macroring is formed in the 4 and 6 position of the sugar, in case of crown ethers 9-11, the ring was built up in the 2,3 vicinal positions [16]. Besides azacrowns $\mathbf{9}, \mathbf{1 0}$ and 11, several analogues have been reported. The same authors also used mannofuranoside as a starting compound to synthesize crown ethers bearing $N$-tosyl moieties, such as 12a-c [17]. To date, as far as we know, no studies have been reported for compounds $\mathbf{7 - 1 2}$ regarding the complex forming or the catalytic activity.

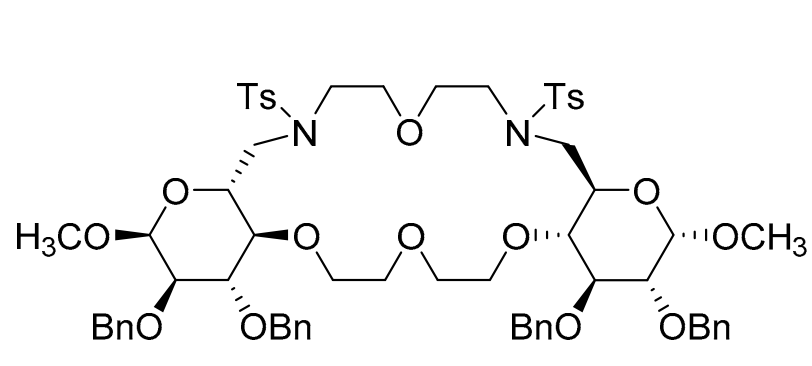

7

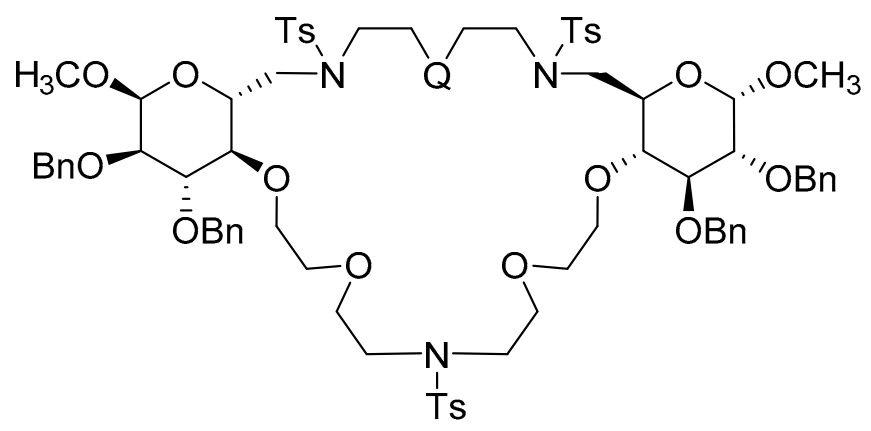

$$
\begin{aligned}
& 8 \mathbf{a} Q=0 \\
& 8 \mathbf{b} Q=N T s
\end{aligned}
$$

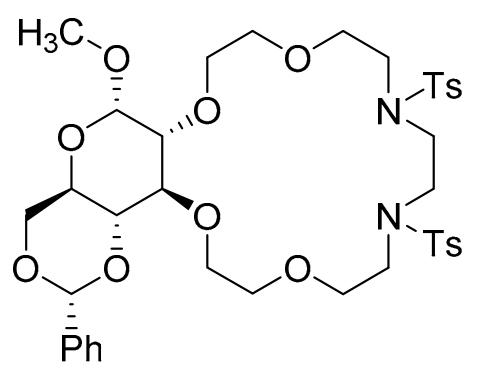

9

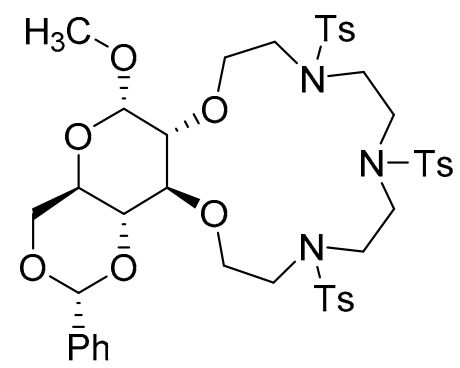

10

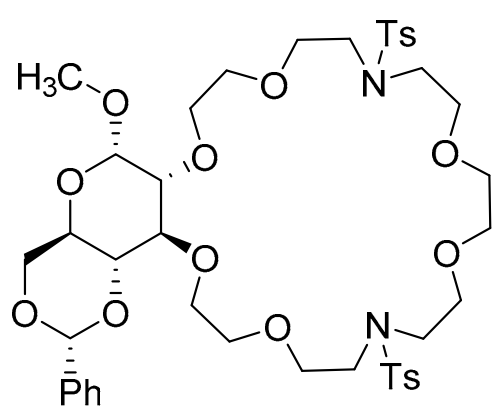

11

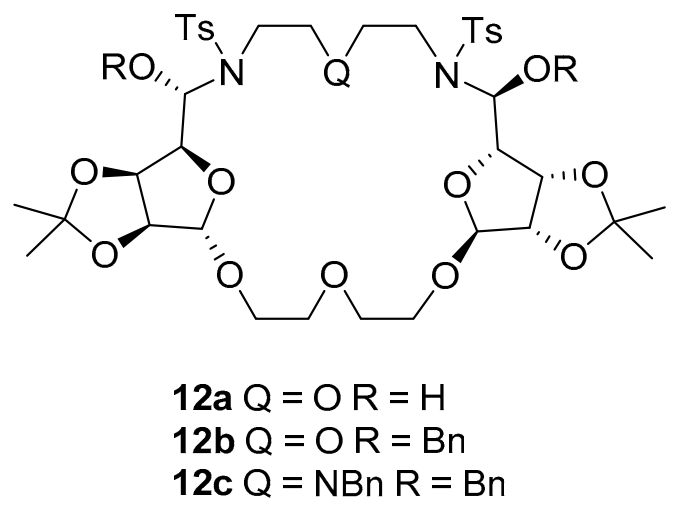

\section{Synthesis and Application of Azacrown Ethers}

\subsection{Preparation of Macrocycles}

In our research group, the first carbohydrate-based crown ethers were synthesized in 1981. Starting from methyl 4,6-O-benzylidene- $\alpha$-D-glucopyranoside, a few 18-crown6-type macrocycles (13a-e) containing two glucose units were prepared. The complex forming ability of crown ethers 13a-e was investigated towards cations; however, catalytic activity was not examined [18]. Later, other derivatives were also synthesized to investigate complex forming ability [19]. 


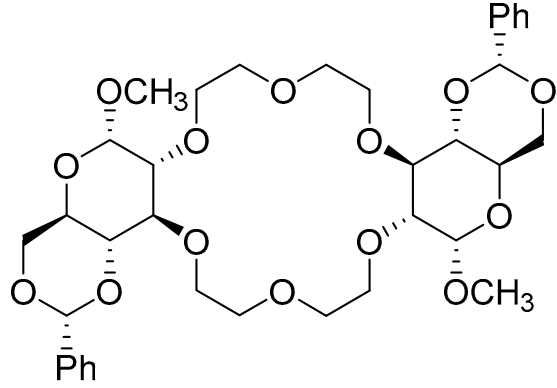

$13 a$

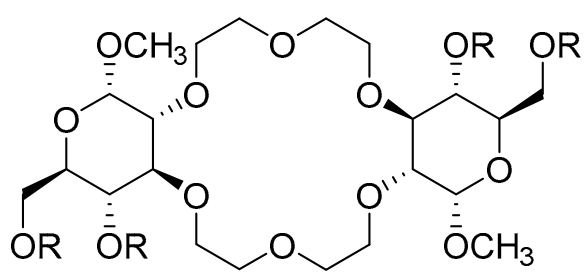

$$
\begin{aligned}
13 b \mathrm{R} & =\mathrm{H} \\
13 c \mathrm{R} & =\mathrm{CH}_{3} \mathrm{CO} \\
13 d \mathrm{R} & =\mathrm{CH}_{3} \\
13 e \mathrm{R} & =\mathrm{C}_{4} \mathrm{H}_{9} \\
13 f \mathrm{R} & =\mathrm{CH}_{2} \mathrm{C}_{6} \mathrm{H}_{5}
\end{aligned}
$$

Using monoaza-15-crown-5 and anhydroallopyranoside $\mathbf{1 4}$ as starting materials, a monoaza macrocycle containing an altropyranoside moiety (15) was created, in which the sugar unit was connected to the macro ring with a single bond (Scheme 1) [20]. During the synthesis, a similar, but glucose-containing, crown compound (16) was also isolated. Crown ethers $\mathbf{1 5}$ and $\mathbf{1 6}$ have not been used as phase transfer catalysts.

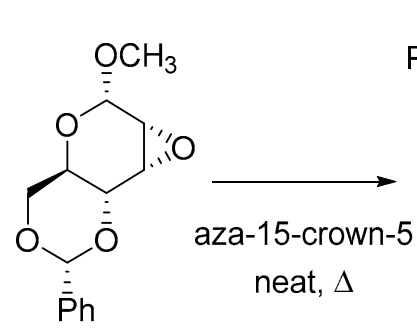

14

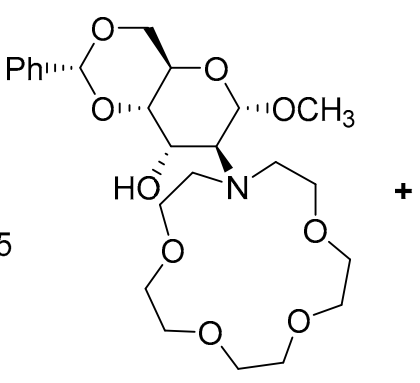

15<smiles>CO[C@H]1OC2COC(c3ccccc3)OC2C(N2CCOCCOCCOCCOC2)[C@H]1O</smiles>

16

Scheme 1. Preparation of crown ethers $\mathbf{1 5}$ and $\mathbf{1 6 .}$

A 2-amino-2-deoxy-altrose derivative, which was prepared from allopyranoside 14, also served as the source of chirality in monoaza-15-crown-5 17 and monoaza-18-crown-6 18 (Scheme 2) [21]. The macro ring was formed during the multi-step synthesis, in contrast to the synthesis of crowns $\mathbf{1 5}$ and $\mathbf{1 6}$, where the pre-formed crown structure was coupled with the sugar.<smiles>CO[C@H]1OC2COC(c3ccccc3)OC2C2CC21</smiles>

14<smiles></smiles>

$17 n=0$

$18 n=1$

Scheme 2. Synthesis of crown ethers $\mathbf{1 7}$ and $\mathbf{1 8 .}$

The first carbohydrate-based monoaza-15-crown-5 lariat ethers (20a-g) were synthesized in 1995, alongside with diazacrown compounds 21 and 22 (Schemes 3 and 4) [22]. The complexing ability of these macrocycles was examined towards various picrate salts. The 
<smiles>CO[C@H]1OC2CO[C@@H](c3ccccc3)O[C@H]2C(O)[C@@H]1O</smiles>

19
1) $\left(\mathrm{ClCH}_{2} \mathrm{CH}_{2}\right)_{2} \mathrm{O}$

$\mathrm{Bu}_{4} \mathrm{NHSO}_{4}$ $50 \% \mathrm{NaOH}$

2) Nal, acetone

3) $\mathrm{R}-\mathrm{NH}_{2}$

$\mathrm{CH}_{3} \mathrm{CN}, \mathrm{Na}_{2} \mathrm{CO}_{3}$<smiles></smiles>

20

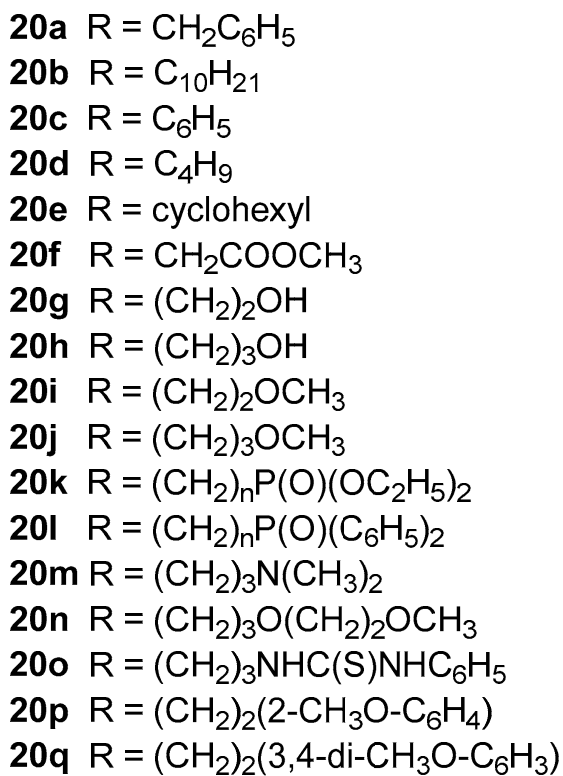

Scheme 3. Synthesis of glucose-based lariat ethers 20.
1) $\left(\mathrm{ClCH}_{2} \mathrm{CH}_{2}\right)_{2} \mathrm{O}$

$\mathrm{Bu}_{4} \mathrm{NHSO}_{4}$ $50 \% \mathrm{NaOH}$

2) Nal, acetone

3) $\mathrm{CH}_{3} \mathrm{CN}, \mathrm{Na}_{2} \mathrm{CO}_{3}$<smiles>NCCN</smiles><smiles>COCCOCCNCCNCCOCCOC1[C@@H]2OC(c3ccccc3)OCC2O[C@H](OC)[C@@H]1O</smiles>

21

or<smiles>CO[C@@H]1OCCOCCNc2ccccc2NCCOCCO[C@H]([O-])[C@@H]2O[C@H](c3ccccc3)OC[C@H]2O1</smiles>

22

Scheme 4. Preparation of diaza-18-crown 6 compounds 21 and 22 derived from glucose.

Catalyst 20h, which has been applied the most in asymmetric syntheses so far, was reported 4 years later [23]. Substituents containing phosphorus were also introduced to the nitrogen of the macro ring. Methyl $\alpha$-D-glucoside-based crown ethers bearing different phosphonoalkyl (20k, $n=1-5)$ [24] and phosphinoxidoalkyl side arms $(201, n=1-5)$ were synthesized to determine the optimal distance between the $\mathrm{N}$ and $\mathrm{P}$ atoms [25]. As can 
be seen from the results of the asymmetric reactions, the side arm strongly influences the catalytic activity and the selectivity of the crown ethers. Substituents bearing different functional groups were introduced to the azacrown ring in macrocycles $20 \mathrm{~m}-\mathbf{o}$ to investigate the impact of the structural changes on the outcome of the asymmetric syntheses [26]. Substituted phenylethyl side chains proved to be effective in case of other carbohydrate-based catalysts, thus, crown compounds $\mathbf{2 0 p}$ and $\mathbf{2 0 q}$ were also prepared [27].

It has been hypothesized, that one of the influencing units in addition to the side arm may be the substituent on the anomeric center. To investigate this idea, a series of monoaza crown ethers derived from phenyl $\beta$-D-glucopyranoside (23a-k) were synthesized [28-30].

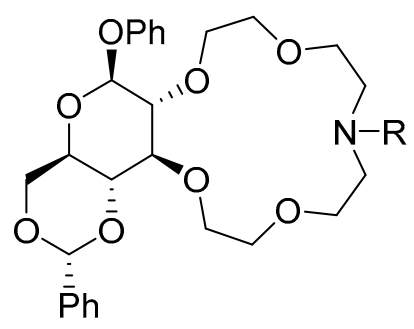

23 23a $\mathrm{R}=\mathrm{C}_{4} \mathrm{H}_{9}$

23b R = cyclohexyl

23c $\mathrm{R}=\mathrm{CH}_{2} \mathrm{C}_{6} \mathrm{H}_{5}$

23d R $=\left(\mathrm{CH}_{2}\right)_{2} \mathrm{C}_{6} \mathrm{H}_{5}$

23e $\mathrm{R}=\left(\mathrm{CH}_{2}\right)_{2} \mathrm{OH}$

23f $\mathrm{R}=\left(\mathrm{CH}_{2}\right)_{2} \mathrm{OCH}_{3}$

23g R $=\left(\mathrm{CH}_{2}\right)_{3} \mathrm{OH}$

23h R $=\left(\mathrm{CH}_{2}\right)_{3} \mathrm{OCH}_{3}$

23i $\mathrm{R}=\left(\mathrm{CH}_{2}\right)_{2}\left(2-\mathrm{CH}_{3} \mathrm{O}-\mathrm{C}_{6} \mathrm{H}_{4}\right)$

23j $\mathrm{R}=\left(\mathrm{CH}_{2}\right)_{2}\left(4-\mathrm{CH}_{3} \mathrm{O}-\mathrm{C}_{6} \mathrm{H}_{4}\right)$

23k R $=\left(\mathrm{CH}_{2}\right)_{2}\left(3,4-\mathrm{di}-\mathrm{CH}_{3} \mathrm{O}-\mathrm{C}_{6} \mathrm{H}_{3}\right)$

To determine whether the protecting group in the 4 and 6 positions of the glucose unit affects the activity of the crown catalyst, compounds $24 \mathbf{a}-\mathbf{d}$ were prepared, in which the benzylidene moiety was replaced by 4,6-di-O-alkyl chains (Scheme 5) [31].<smiles>CO[C@H]1OC2CO[C@@H](P)O[C@H]2C(O)[C@H]1O</smiles>

19
1) $\left(\mathrm{ClCH}_{2} \mathrm{CH}_{2}\right)_{2} \mathrm{O}$

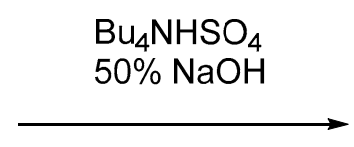

2) Nal, acetone

3) $\mathrm{TsNH}_{2}$ $\mathrm{CH}_{3} \mathrm{CN}, \mathrm{Na}_{2} \mathrm{CO}_{3}$

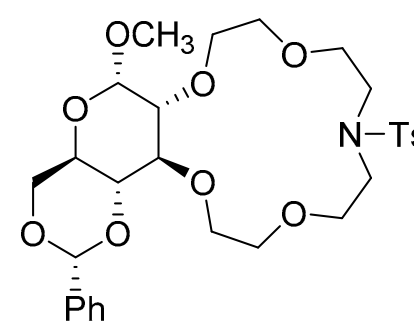

$20 \mathrm{r}$
1) $\mathrm{CH}_{3} \mathrm{COOH}$

2) $\mathrm{CH}_{3} \mathrm{I}$ or $\mathrm{BuBr}$ $\mathrm{NaH}, \mathrm{DMF}$

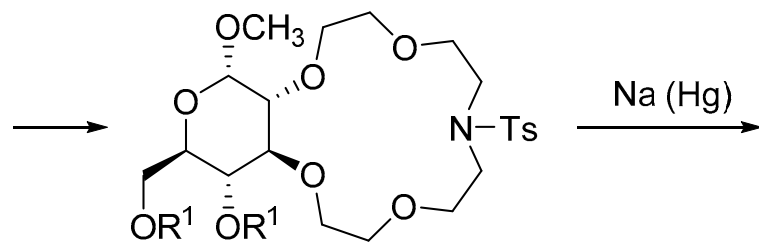<smiles>[R10]OC1C(CO)O[C@@H](OC)[C@@H]1OCCOCCNCCOC</smiles>

$$
\begin{aligned}
& \text { 24a } \mathrm{R}=\mathrm{CH}_{3} \\
& \text { 24b } \mathrm{R}=\mathrm{C}_{4} \mathrm{H}_{9}
\end{aligned}
$$

24c $\mathrm{R}=\mathrm{CH}_{3}$

24d R $=\mathrm{C}_{4} \mathrm{H}_{9}$

Scheme 5. Synthesis of 4,6-di-O-alkyl glucoside-based catalysts $24 a-d$.

The 4,6-dibutyl-substituted 24e-h derivatives with other side chains have also been prepared. For this, the benzylidene protecting group of the methyl glucopyranoside 19 was removed and the free $\mathrm{OH}$ groups were butylated before the three-step cyclization (Scheme 6) [32]. 


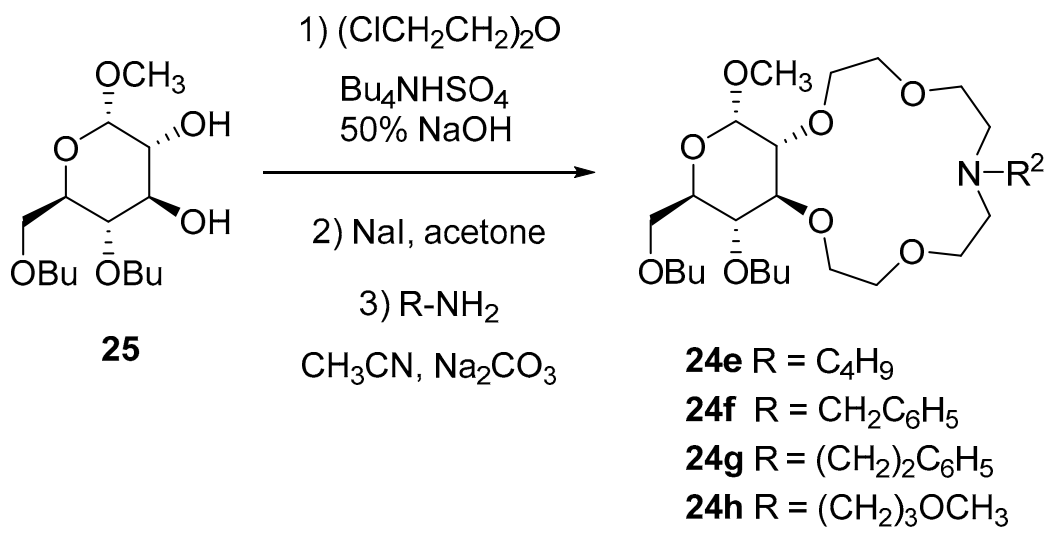

Scheme 6. Synthesis of crown ethers $24 \mathbf{e}-\mathbf{h}$ with 4,6-di-O-butyl glucoside groups.

As a different source of chirality, D-galactose was also used to prepare monoaza crown compounds 26a-g [22,24,27,33,34]. Galactose is the C-4 epimer of glucose, both of which can form pyranose ring. While in the benzylidene-protected glucopyranoside, the sixmembered rings are in anti (trans) annulation (planar), in benzylidene galactopyranoside the rings are syn- (cis) annulated (L-shape). This structural difference can also affect the selectivity in the reactions.

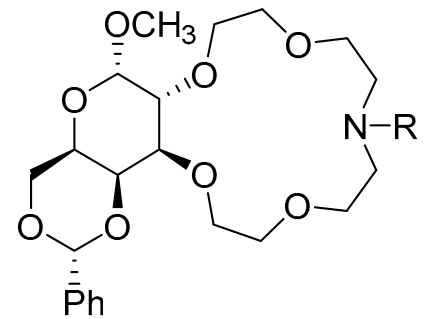<smiles>[R]N1CCOCCO[C@@H]([C@H]2COC(C)(C)O2)[C@@H]([C@H]2COC(C)(C)O2)OCCOCC1</smiles>
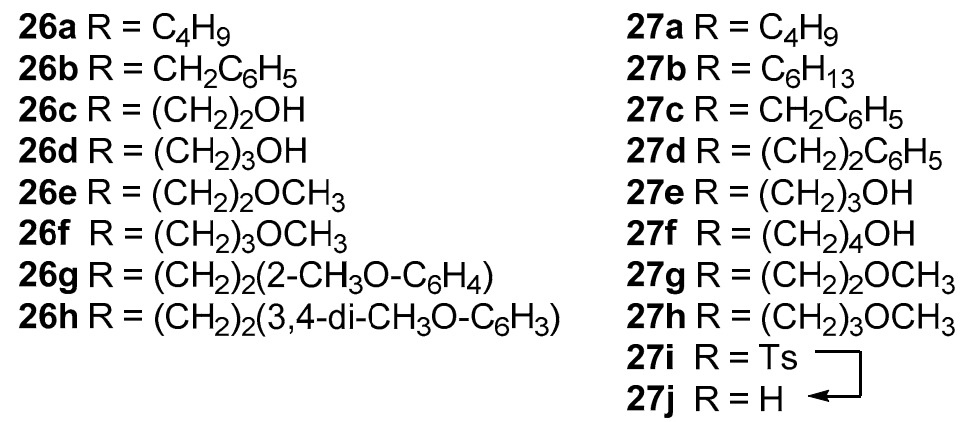

Sugar alcohol, D-mannitol can be transformed into a derivative, which contains two vicinal hydroxy groups, thus, it was suitable for the three-step ring-closure procedure. The mannitol moiety provides a different and less rigid structure to the catalysts. To investigate the effect of the deviation in flexibility, lariat ethers $\mathbf{2 7} \mathbf{a}-\mathbf{h}$ were synthesized by the previously described method using different primary amines, and tosyl amide for $27 \mathbf{i}$ in the ring-closure step. Reaction of $27 i$ with sodium amalgam resulted in the formation of $27 \mathbf{j}$ [35].

Mannose, which is the C-2 epimer of glucose was chosen for synthesis of sugar-based crown ethers. Whereas it has been proved previously that the sugar-based macrocycles with hydrocarbon-type side arms are generally ineffective in model reactions, mannose-based crown ethers with heteroatom-containing side arms $\mathbf{2 8 a}-\mathbf{d}$ were prepared only. Compound 28d was reduced with $\mathrm{Na}(\mathrm{Hg})$ into $28 \mathbf{e}[36,37]$. 
<smiles>[R]O[C@@H]1OCCOCCN(C)CCOCCO[C@H]([O-])[C@@H]2O[C@H](c3ccccc3)OC[C@@H]2O1</smiles>

28a $\mathrm{R}=\left(\mathrm{CH}_{2}\right)_{2} \mathrm{OH}$

28b R $=\left(\mathrm{CH}_{2}\right)_{3} \mathrm{OH}$

28c $\mathrm{R}=\left(\mathrm{CH}_{2}\right)_{3} \mathrm{OCH}_{3}$

28d R $=$ Ts

$28 \mathrm{e} R=\mathrm{H}$<smiles>CO[C@H]1OC2COC(c3ccccc3)O[C@H]2C(OCCOCCN(C)CCO)[C@H]1O</smiles>

29

In glucose, hydroxy groups in C-2 and C-3 positions are equatorial. In mannose, $\mathrm{OH}$-function of $\mathrm{C}-2$ is axial. Mannose-based catalysts 28a-e were synthesized to determine whether this has a significant impact on the selectivity. Altrose is another hexopyranoside, in which hydroxy functions in C-2 and C-3 are axial. Using altrose as a staring material, lariat ether $\mathbf{2 9}$ was synthesized, in which-compared to the glucose-based macrocycles $\mathbf{2 0}$ -a different anti (trans) annulation can be found between the macro ring and the pyranoside unit [38].

It was found that the protecting group of the sugar unit in crown ethers 24 also has an impact on the enantioselectivity, thus, other crown compounds derived from glucose were synthesized. Instead of the benzylidene group, naphthylidene (30a-b) and isopropylidene moieties (31a-b) were introduced to the macrocycles [39]. Hydrogenation of catalysts $\mathbf{2 0 h}$ and $20 \mathbf{j}$ resulted in lariat ethers $32 \mathbf{a}-\mathbf{b}$ bearing free OH-groups in the 4 and 6 positions (Scheme 7).<smiles>[R]N1CCOCCO[C@H](OCCO[C@H]2[C@@H](OC)O[C@@H](c3ccccc3)OC[C@H]2OC)[C@H]1O</smiles>

20h R $=\left(\mathrm{CH}_{2}\right)_{3} \mathrm{OH}$ 20j $\mathrm{R}=\left(\mathrm{CH}_{2}\right)_{3} \mathrm{OCH}_{3}$<smiles>[R]N1CCOCCO[C@H](OCCO)[C@H](O)[C@@H](O)[C@@H]1CO</smiles>

32a $\mathrm{R}=\left(\mathrm{CH}_{2}\right)_{3} \mathrm{OH}$ 32b R $=\left(\mathrm{CH}_{2}\right)_{3} \mathrm{OCH}_{3}$

Scheme 7. Removal of the benzylidene group of catalysts $20 \mathrm{~h}$ and $20 \mathrm{j}$ to obtain compounds $32 \mathrm{a}$ and $32 b$.

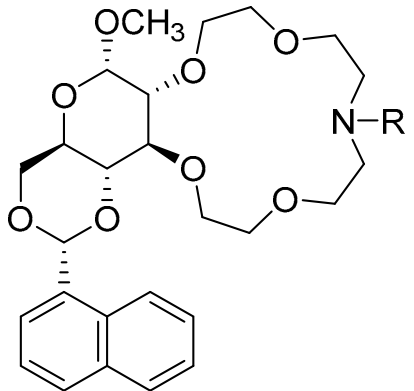

30a R $=\left(\mathrm{CH}_{2}\right)_{3} \mathrm{OH}$ 30b R $=\left(\mathrm{CH}_{2}\right)_{3} \mathrm{OCH}_{3}$<smiles>[R]N1CCOCCO[C@@H]2[C@H](COC(C)(C)C)O[C@@H](OC)[C@@H](OC)[C@@H]2OCCOCCN1</smiles>

31a R $=\left(\mathrm{CH}_{2}\right)_{3} \mathrm{OH}$

31b R $=\left(\mathrm{CH}_{2}\right)_{3} \mathrm{OCH}_{3}$ 
An aldopentose, L-arabinose served as the source of chirality in crown compounds 33a-c. When arabinose is reacted with acetone or benzaldehyde, a six-membered pyranoside ring can be formed, while two vicinal hydroxy functions remain unprotected. After the three-step procedure of ring formation, the crown ring was connected to the carbohydrate unit in syn-annulation in macrocycles 33a-c [40].<smiles>[R3]N1CCOCCO[C@H]2CO[C@H](OCCOCC1)[C@@H](OC)[R]([R])([R])O2</smiles>

33a $\mathrm{R}^{1}=\mathrm{R}^{2}=\mathrm{CH}_{3} ; \mathrm{R}^{3}=\left(\mathrm{CH}_{2}\right)_{3} \mathrm{OH}$ 33b R $\mathrm{R}^{1}=\mathrm{R}^{2}=\mathrm{CH}_{3} ; \mathrm{R}^{3}=\left(\mathrm{CH}_{2}\right)_{3} \mathrm{OCH}_{3}$ 33c $\mathrm{R}^{1}=\mathrm{C}_{6} \mathrm{H}_{5} \mathrm{R}^{2}=\mathrm{H} ; \mathrm{R}^{3}=\left(\mathrm{CH}_{2}\right)_{3} \mathrm{OH}$<smiles>[R]C1O[C@H](OC)C[C@@H]([C@H]2NCCOCCO2)OCCOCCN1[R]</smiles>

$$
\begin{aligned}
& \text { 34a R } \mathrm{R}^{1}=\mathrm{CH}_{3} ; \mathrm{R}^{2}=\left(\mathrm{CH}_{2}\right)_{3} \mathrm{OH} \\
& \text { 34b R } \mathrm{R}^{1}=\mathrm{CH}_{3} ; \mathrm{R}^{2}=\left(\mathrm{CH}_{2}\right)_{3} \mathrm{OCH} \mathrm{CH}_{3} \\
& \text { 34c R } \mathrm{R}^{1}=\mathrm{CH}_{2} \mathrm{O}\left(4-\mathrm{CH}_{3} \mathrm{O}-\mathrm{C}_{6} \mathrm{H}_{4}\right) ; \mathrm{R}^{2}=\left(\mathrm{CH}_{2}\right)_{3} \mathrm{OH} \\
& \text { 34d R } \mathrm{R}^{1}=\mathrm{CH}_{2} \mathrm{O}\left(4-\mathrm{CH}_{3} \mathrm{O}-\mathrm{C}_{6} \mathrm{H}_{4}\right) ; \mathrm{R}^{2}=\left(\mathrm{CH}_{2}\right)_{3} \mathrm{OCH} \mathrm{CH}_{3}
\end{aligned}
$$

An unnatural carbohydrate, 2-deoxy-ribo-hexopyranoside was prepared from glucose, and then fused to the monoaza-15-crown-5 ring resulting in catalysts 34a-d [41]. In this case, the annulation of the sugar unit and the macro ring was also syn, but in this case, C-3 and C-4 are the connecting atoms.

Monosaccharides can form not only pyranose but furanose rings too. A few crown compounds containing a glucofuranoside moiety $(35 \mathbf{a}-\mathbf{d}, \mathbf{3 6 a}-\mathbf{b})$ were synthesized starting from glucose. In one type (35a-d), the furanoside unit is attached to the macrocycle by a single bond. while in the other, the five-membered furanoside is fused to the crown ring $(36 \mathbf{a}-\mathbf{b})$. From D-xylose, catalysts $37 \mathbf{a}-\mathbf{b}$ were prepared having an analogous structure to glucofuranoside-based crown ethers $36 \mathbf{a}-\mathbf{b}$. When the complexing ability was examined, surprisingly, the ion selectivity of crowns $35 \mathbf{a}-\mathbf{d}$ towards silver was measured to be up to 30 times higher than that for sodium [42].<smiles>[Z12]O[C@H]1[C@@H]([C@H]2COCCOCCN([R2])CCOCCO2)O[C@@H]2OC(C)(C)O[C@@H]12</smiles>

35a $\mathrm{R}^{1}=\mathrm{CH}_{2} \mathrm{C}_{6} \mathrm{H}_{5} ; \mathrm{R}^{2}=\left(\mathrm{CH}_{2}\right)_{3} \mathrm{OH}$

35b R ${ }^{1}=\mathrm{CH}_{2} \mathrm{C}_{6} \mathrm{H}_{5} ; \mathrm{R}^{2}=\left(\mathrm{CH}_{2}\right)_{3} \mathrm{OCH}_{3}$

$35 \mathrm{c} \mathrm{R}^{1}=\mathrm{C}_{3} \mathrm{H}_{7} ; \mathrm{R}^{2}=\left(\mathrm{CH}_{2}\right)_{3} \mathrm{OH}$

35d R $\mathrm{R}^{1}=\mathrm{C}_{3} \mathrm{H}_{7} ; \mathrm{R}^{2}=\left(\mathrm{CH}_{2}\right)_{3} \mathrm{OCH}_{3}$<smiles></smiles>

36a $\mathrm{R}=\left(\mathrm{CH}_{2}\right)_{3} \mathrm{OH}$ 36b R $=\left(\mathrm{CH}_{2}\right)_{3} \mathrm{OCH}_{3}$<smiles>[R]CNCCOCCO[C@@H]1[C@H](COCCOCCN)O[C@H]2OC(C)(C)O[C@H]21</smiles>

37a $\mathrm{R}=\left(\mathrm{CH}_{2}\right)_{3} \mathrm{OH}$ 37b R $=\left(\mathrm{CH}_{2}\right)_{3} \mathrm{OCH}_{3}$

In addition to mannitol, another sugar alcohol, L-threitol was also used as a source of chirality in crown ethers [43]. Threitol-based catalysts $\mathbf{3 8 a}-\mathbf{f}$ were prepared in three steps from 1,4-di-O-alkylated threitol derivatives, which could be easily synthesized starting from diethyl tartrate. 
It was assumed that the ketal groups in the mannitol moiety can have an impact on the enantioselectivity. Therefore, the number of mannitol-based catalysts was increased by using different protecting groups during the syntheses, resulting in compounds $39 \mathbf{a}-\mathbf{b}$ and 40a-b [44].<smiles>[R20]C[C@H]1OCCOCCN([R])CCOCCO[C@@H]1C[R20]</smiles>

38a R ${ }^{1}=\mathrm{CH}_{3} ; \mathrm{R}^{2}=\left(\mathrm{CH}_{2}\right)_{3} \mathrm{OH}$

38b R ${ }^{1}=\mathrm{CH}_{3} ; \mathrm{R}^{2}=\left(\mathrm{CH}_{2}\right)_{3} \mathrm{OCH}_{3}$

38c $\mathrm{R}^{1}=\mathrm{CH}_{2} \mathrm{C}_{6} \mathrm{H}_{5} ; \mathrm{R}^{2}=\left(\mathrm{CH}_{2}\right)_{3} \mathrm{OH}$

38d R $\mathrm{R}^{1}=\mathrm{CH}_{2} \mathrm{C}_{6} \mathrm{H}_{5} ; \mathrm{R}^{2}=\left(\mathrm{CH}_{2}\right)_{3} \mathrm{OCH}_{3}$

38 e $\mathrm{R}^{1}=\mathrm{C}_{4} \mathrm{H}_{9} ; \mathrm{R}^{2}=\left(\mathrm{CH}_{2}\right)_{3} \mathrm{OH}$

$38 f \mathrm{R}^{1}=\mathrm{C}_{4} \mathrm{H}_{9} ; \mathrm{R}^{2}=\left(\mathrm{CH}_{2}\right)_{3} \mathrm{OCH}_{3}$<smiles>[R]N1CCOCCO[C@H]([C@H]2COC(c3ccccc3)(c3ccccc3)O2)[C@H](OCCOC2(c3ccccc3)[CH]CO2)O1</smiles>

39a $\mathrm{R}=\left(\mathrm{CH}_{2}\right)_{3} \mathrm{OH}$

39b R $=\left(\mathrm{CH}_{2}\right)_{3} \mathrm{OCH}_{3}$



40a $\mathrm{R}=\left(\mathrm{CH}_{2}\right)_{3} \mathrm{OH}$ 40b $\mathrm{R}=\left(\mathrm{CH}_{2}\right)_{3} \mathrm{OCH}_{3}$

As mentioned before, one of the influencing moieties may be the substituent on the anomeric center. Therefore, additional glucose-based lariat ethers were synthesized to gain further information on the structure-activity relationship [27,45]. Catalysts 20h and $\mathbf{4 2 a}, \mathbf{4 1 a}$ and $\mathbf{4 2 b}$, and as well as $\mathbf{4 1 b}$ and $\mathbf{4 2 c}$ are epimer pairs, the only difference in the absolute configuration is on C-1.

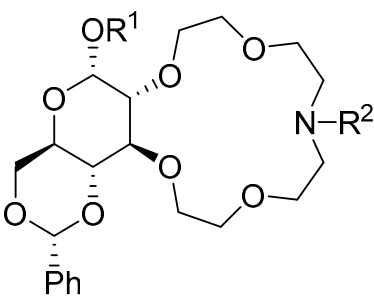

41a $\mathrm{R}^{1}=\mathrm{C}_{2} \mathrm{H}_{5} ; \mathrm{R}^{2}=\left(\mathrm{CH}_{2}\right)_{3} \mathrm{OH}$ 41b $\mathrm{R}^{1}=\mathrm{CH}\left(\mathrm{CH}_{3}\right)_{2} ; \mathrm{R}^{2}=\left(\mathrm{CH}_{2}\right)_{3} \mathrm{OH}$

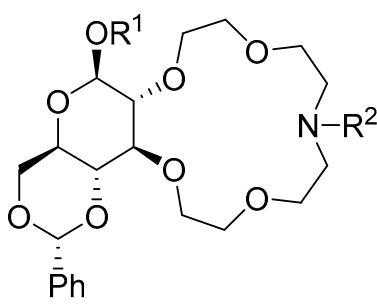

42a $\mathrm{R}^{1}=\mathrm{CH}_{3} ; \mathrm{R}^{2}=\left(\mathrm{CH}_{2}\right)_{3} \mathrm{OH}$

42b $\mathrm{R}^{1}=\mathrm{C}_{2} \mathrm{H}_{5} ; \mathrm{R}^{2}=\left(\mathrm{CH}_{2}\right)_{3} \mathrm{OH}$

42c $\mathrm{R}^{1}=\mathrm{CH}\left(\mathrm{CH}_{3}\right)_{2} ; \mathrm{R}^{2}=\left(\mathrm{CH}_{2}\right)_{3} \mathrm{OH}$

42d $\mathrm{R}^{1}=$ naphthalen-2-yl; $\mathrm{R}^{2}=\left(\mathrm{CH}_{2}\right)_{3} \mathrm{OH}$

42e $\mathrm{R}^{1}=$ naphthalen-2-yl; $\mathrm{R}^{2}=\left(\mathrm{CH}_{2}\right)_{2}\left(3,4-\mathrm{di}-\mathrm{CH}_{3} \mathrm{O}-\mathrm{C}_{6} \mathrm{H}_{3}\right)$

42f $\mathrm{R}^{1}=\mathrm{CH}_{3} ; \mathrm{R}^{2}=\left(\mathrm{CH}_{2}\right)_{2}\left(3,4-\mathrm{di}-\mathrm{CH}_{3} \mathrm{O}-\mathrm{C}_{6} \mathrm{H}_{3}\right)$<smiles>CC(C)O[C@H]1OC2CO[C@@H](O)OC2C(OCCOCCN(C)CO)[C@H]1O</smiles>

43<smiles>[R]C1CCOCCOC2C(OCCOC1)C(O)OC1COC(c3ccccc3)OC12</smiles>

44a $\mathrm{R}^{1}=\mathrm{CH}_{3} ; \mathrm{R}^{2}=\left(\mathrm{CH}_{2}\right)_{3} \mathrm{OH}$

$44 \mathrm{~b} \mathrm{R}^{1}=\mathrm{C}_{2} \mathrm{H}_{5} ; \mathrm{R}^{2}=\left(\mathrm{CH}_{2}\right)_{3} \mathrm{OH}$

44c $\mathrm{R}^{1}=\mathrm{CH}\left(\mathrm{CH}_{3}\right)_{2} ; \mathrm{R}^{2}=\left(\mathrm{CH}_{2}\right)_{3} \mathrm{OH}$

$44 d R^{1}=\mathrm{C}_{6} \mathrm{H}_{5} ; \mathrm{R}^{2}=\left(\mathrm{CH}_{2}\right)_{3} \mathrm{OH}$

$44 \mathrm{e} \mathrm{R}^{1}=4-\mathrm{CH}_{3} \mathrm{O}-\mathrm{C}_{6} \mathrm{H}_{3} ; \mathrm{R}^{2}=\left(\mathrm{CH}_{2}\right)_{3} \mathrm{OH}$

$44 f \mathrm{R}^{1}=4-\mathrm{Cl}-\mathrm{C}_{6} \mathrm{H}_{3} ; \mathrm{R}^{2}=\left(\mathrm{CH}_{2}\right)_{3} \mathrm{OH}$

$44 \mathrm{R} \mathrm{R}^{1}=\mathrm{C}_{6} \mathrm{H}_{5} ; \mathrm{R}^{2}=\left(\mathrm{CH}_{2}\right)_{2}\left(3,4-\mathrm{di}-\mathrm{CH}_{3} \mathrm{O}-\mathrm{C}_{6} \mathrm{H}_{3}\right)$ 
The effect of the anomeric position on the enantioselectivity was also studied in the case of galactose-based lariat ethers. Crown compound 43 was synthesized from isopropyl $\alpha$-D-galactoside, while alkyl and aryl 4,6-O-benzylidene- $\beta$-galactopyranosides were the key intermediates in the synthesis of macrocycles $\mathbf{4 4 a - f}[27,46]$.

Xylal- $(45 a-b, 46)$ and arabinal-based $(47 a-b, 48)$ lariat ethers were synthesized to examine the effect of fewer stereogenic centers in the sugar unit [47]. Crown catalysts 45a, 46, and as well as $47 a$ and 48 are enantiomeric pairs. Unsaturated monosaccharides bearing free vicinal $\mathrm{OH}$-groups, namely D- and L-xylal, and D- and L-arabinal can be prepared from the appropriate carbohydrates in four steps.<smiles>CN1CCOCCO[C@H]2C=COC[C@H]2OCCO1</smiles>

45a $\mathrm{R}=\mathrm{H}$ 45b $\mathrm{R}=\mathrm{CH}_{3}$<smiles></smiles>

47a $\mathrm{R}=\mathrm{H}$ $47 \mathrm{~b} \mathrm{R}=\mathrm{CH}_{3}$<smiles>OCCN1CCOCCO[C@@H]2C=COC[C@H]2OCCOC1</smiles>

46<smiles></smiles>

48

\subsection{Enantioselective Syntheses}

\subsubsection{Michael Addition of 2-Nitropropane}

The catalytic properties of the carbohydrate-based crown ethers were not investigated in the Hungarian research group until 1996, only measurements for complex forming ability were performed. Using a few derivatives of the two-glucose unit-containing 18-crown-6 (1), selective transportation of chiral ammonium salts was examined, but the experiments resulted in racemic mixtures [48].

The first asymmetric reaction, in which carbohydrate-based (lariat) azacrown compounds were investigated, was the Michael addition of 2-nitropropane (50) to chalcone (49, $\left.\mathrm{Ar}^{1}=\mathrm{Ar}^{2}=\mathrm{C}_{6} \mathrm{H}_{5}\right)($ Scheme 8$)[49,50]$. In the presence of catalysts $\mathbf{2 0 a}-\mathbf{g}$, the $S$ enantiomer of Michael adduct 51 was formed in excess. Lariat ether $\mathbf{2 0} \mathbf{g}$ having a $\left(\mathrm{CH}_{2}\right)_{2} \mathrm{OH}$ side arm induced $34-65 \%$ ee (enantiomeric excess), depending on the conditions (Table 1, entry 1). Increasing the distance between the nitrogen and the oxygen led to higher enantiomeric excess. Application of crown ether $20 \mathrm{~h}$ bearing a $\left(\mathrm{CH}_{2}\right)_{3} \mathrm{OH}$ group resulted in an ee value of $85 \%$ (Table 1, entry 2) [24]. Replacement of the $\mathrm{OH}$ with a methoxy group in the hydroxyethyl chain also had a positive effect on the selectivity, $87 \%$ ee was measured in the presence of compound 20i (Table 1, entry 4). When methyl $\alpha$-D-glucoside-based crown ethers 20k $(n=1-5)$ were tested, it turned out that the phosphonoalkyl chain has an optimal length. Using catalyst 20k $(n=4)$ with $\left(\mathrm{CH}_{2}\right)_{4}$ spacer led to $82 \%$ enantioselectivity (Table 1 , entry 5) [24]. The same phenomenon was observed in the case of $\mathbf{2 0 1}(n=4)$ with the spacer $\left(\mathrm{CH}_{2}\right)_{4}$, which generated 95\% ee (Table 1, entry 6) [25,51]. Despite the similarity, macrocycles 201 bearing phosphinoxidoalkyl groups preferred the formation of the $R$ enantiomer of 51, while using phosphonoalkyl-substituted 20k, the $S$ isomer was in excess. 


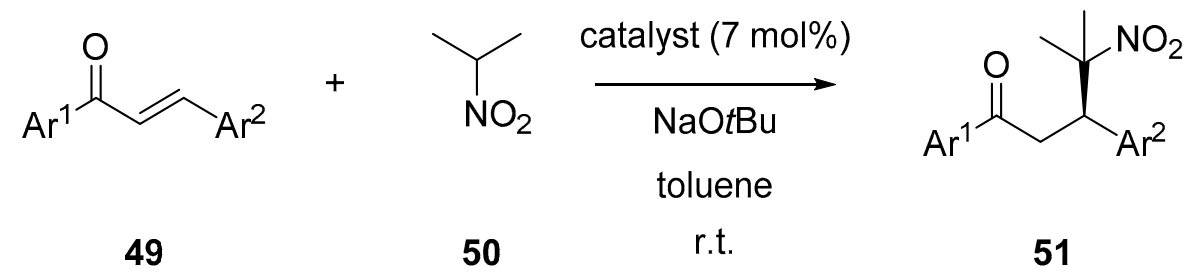

Scheme 8. Michael addition of 2-nitropropane (50) to chalcones (49).

Table 1. Effect of crown ethers in the Michael addition of 2-nitropropane (50) to chalcones (49).

\begin{tabular}{cccccc}
\hline Entry & $\mathbf{A r}^{\mathbf{1}}$ & $\mathbf{A r}^{\mathbf{2}}$ & Catalyst & Yield, $\%$ & ee, $\%$ \\
\hline 1 & $\mathrm{C}_{6} \mathrm{H}_{5}$ & $\mathrm{C}_{6} \mathrm{H}_{5}$ & $\mathbf{2 0 g}$ & 91 & 65 \\
2 & $\mathrm{C}_{6} \mathrm{H}_{5}$ & $\mathrm{C}_{6} \mathrm{H}_{5}$ & $\mathbf{2 0 h}$ & 53 & 85 \\
3 & Naphthalen-1-yl & $\mathrm{C}_{6} \mathrm{H}_{5}$ & $\mathbf{2 0 h}$ & 35 & 87 \\
4 & $\mathrm{C}_{6} \mathrm{H}_{5}$ & $\mathrm{C}_{6} \mathrm{H}_{5}$ & $\mathbf{2 0 i}$ & 45 & 87 \\
5 & $\mathrm{C}_{6} \mathrm{H}_{5}$ & $\mathrm{C}_{6} \mathrm{H}_{5}$ & $\mathbf{2 0 k}(n=4)$ & 39 & 82 \\
6 & $\mathrm{C}_{6} \mathrm{H}_{5}$ & $\mathrm{C}_{6} \mathrm{H}_{5}$ & $\mathbf{2 0 1}(n=4)$ & 43 & 95 \\
7 & $\mathrm{C}_{6} \mathrm{H}_{5}$ & $\mathrm{C}_{6} \mathrm{H}_{5}$ & $\mathbf{2 3 d}$ & 78 & 82 \\
8 & $\mathrm{C}_{6} \mathrm{H}_{5}$ & $\mathrm{C}_{6} \mathrm{H}_{5}$ & $\mathbf{2 3 e}$ & 71 & 45 \\
9 & $\mathrm{C}_{6} \mathrm{H}_{5}$ & $\mathrm{C}_{6} \mathrm{H}_{5}$ & $\mathbf{2 3 f}$ & 65 & 60 \\
10 & $\mathrm{C}_{6} \mathrm{H}_{5}$ & $\mathrm{C}_{6} \mathrm{H}_{5}$ & $\mathbf{2 4 d}$ & 82 & 90 \\
11 & $\mathrm{C}_{6} \mathrm{H}_{5}$ & $\mathrm{C}_{6} \mathrm{H}_{5}$ & $\mathbf{2 4 h}$ & 53 & 55 \\
12 & $\mathrm{C}_{6} \mathrm{H}_{5}$ & $\mathrm{C}_{6} \mathrm{H}_{5}$ & $\mathbf{2 6 e}$ & 34 & 52 \\
13 & $\mathrm{C}_{6} \mathrm{H}_{5}$ & $\mathrm{C}_{6} \mathrm{H}_{5}$ & $\mathbf{2 7 e}$ & 39 & 40 \\
14 & $\mathrm{C}_{6} \mathrm{H}_{5}$ & $\mathrm{C}_{6} \mathrm{H}_{5}$ & $\mathbf{2 7 j}$ & 38 & 67 \\
15 & $\mathrm{C}_{6} \mathrm{H}_{5}$ & $\mathrm{C}_{6} \mathrm{H}_{5}$ & $\mathbf{2 8 b}$ & 37 & $92(S)$ \\
16 & Naphthalen-1-yl & $\mathrm{C}_{6} \mathrm{H}_{5}$ & $\mathbf{2 8 b}$ & 39 & 84 \\
\hline
\end{tabular}

In the Michael addition, substituted chalcone derivatives were also used as the acceptor. Applying catalysts $20 \mathbf{i}$ and $20 \mathbf{k}(n=4)$ it was observed that substituents on the aromatic rings, regardless of the position, led to reduced enantiomeric excess [52]. In the presence of $20 \mathrm{~h}$ and $20 \mathrm{j}$, the addition of 2-nitropropane (50) to chalcone analogues (49) gave similar results, i.e., the substitution of the aromatic ring or replacement of the phenyl group to other aromatic moieties lowered the enantioselectivity [53].

When the efficiency of crown ethers derived from phenyl $\beta$-D-glucopryanoside 23a-g was examined in this Michael addition, it was proven again that the enantioselectivity highly depends on the structure of the side arm (as well). Among the hydrocarbon substituents of the nitrogen, the phenylethyl group was the most effective; catalyst 23d generated $82 \%$ ee (Table 1, entry 7 ). In the case of $23 \mathbf{e}$ and $23 \mathrm{f}$, in which the side arm is a hydroxyethyl or a methoxyethyl group respectively, lower ee values were measured ( $45 \%$ and $60 \%$, respectively) (Table 1, entries 8 and 9) [28]. At lower temperature, the enantiomeric excess and the yield decreased drastically [29].

When macrocycles $24 a-d$ bearing alkyl substituents in the 4 and 6 positions were applied as phase transfer catalysts, poor enantioselectivity was observed, except for compound $\mathbf{2 4 d}$, which generated an ee of $90 \%$ (Table 1, entry 10) [31]. The presence of a side arm in macrocycles $\mathbf{2 4 e -} \mathbf{h}$ negatively affected the asymmetric induction, the best enantioselectivity was achieved using crown ether $24 \mathrm{~h}$ of the above-mentioned ones (55\% ee) (Table 1, entry 11) [32].

Compared to the glucose-based analogous macrocycles, the galactose-containing catalysts generated lower enantiomeric excess, e.g., product 51 had an optical purity of $52 \%$ when lariat ether 26e was used (Table 1, entry 12) [23].

Applying mannitol-based crown ethers (27), the less rigid structure proved to be insufficient to reach high enantioselectivity in this Michael addition. Substitution of the azacrown structure on the nitrogen affected the asymmetric induction negatively. While 
product 51 was formed in an ee of $67 \%$ using catalyst $\mathbf{2 7} \mathbf{j}$, lariat ether $\mathbf{2 7}$ e showed only $40 \%$ enantioselectivity (Table 1, entries 13 and 14) [35].

Among the methyl $\alpha$-D-mannoside-based lariat ethers, $\mathbf{2 8 b}$ was the most efficient in the Michael addition of 2-nitropropane (50) (92\% ee) (Table 1, entry 15) [38]. Crown ether $\mathbf{2 0 h}$ derived from glucose and mannose-based $\mathbf{2 8 b}$ was compared in detail in the Michael addition of 2-nitropropane to enones [54]. In the reaction of chalcone (49, $\left.\mathrm{Ar}^{1}=\mathrm{Ar}^{2}=\mathrm{C}_{6} \mathrm{H}_{5}\right)$, macrocycles $20 \mathrm{~h}$ and $\mathbf{2 8 b}$ preferred the formation of opposite enantiomers. Application of chalcone analogues resulted in lower ee values in each cases, except for compound $\mathbf{5 1}$ with $\mathrm{Ar}^{1}=$ naphthalen-1-yl and $\mathrm{Ar}^{2}=\mathrm{C}_{6} \mathrm{H}_{5}$ groups ( $87 \%$ and $84 \%$ ee, respectively) (Table 1 , entries 3 and 16).

\subsubsection{Michael Addition of a Phosphonoglycine Derivative}

In a collaboration with an organophosphorus research group, a new asymmetric Michael addition has been published. Synthesis of chiral phosphonoglycine derivatives $\mathbf{5 4}$ (ee up to $86 \%$ ) has been developed using phenyl $\beta$-glucopyranoside-based crown ethers 23g-i as phase transfer catalysts (Scheme 9) [55]. The best results were obtained in the presence of lariat ether $23 i$ with acrylonitrile $\left(53, \mathrm{R}^{1}=\mathrm{R}^{2}=\mathrm{H}, \mathrm{EWG}=\mathrm{CN}\right)$ and crotonitrile $\left(53, \mathrm{R}^{1}=\mathrm{CH}_{3}, \mathrm{R}^{2}=\mathrm{H}, \mathrm{EWG}=\mathrm{CN}\right)$ as acceptors $(75 \%$ and $86 \%$ ee, respectively) (Table 2 , entries 1 and 2), however, the asymmetric induction was highly dependent on the structure of 53. Later, the number of applied crown compounds has been expanded by synthesizing phenyl $\beta$-glucopyranoside-based catalysts with different side arms (e.g., $\mathbf{2 3} \mathbf{j}-\mathbf{k}$ ), as well as further Michael acceptors having been investigated [30]. Enantioselectivity was the highest in case of nitrile compounds $(\mathbf{5 3}, \mathrm{EWG}=\mathrm{CN})$. In the presence of lariat ether $\mathbf{2 3 k}$, the Michael addition of crotonitrile $\left(53, \mathrm{R}^{1}=\mathrm{CH}_{3}, \mathrm{R}^{2}=\mathrm{H}, \mathrm{EWG}=\mathrm{CN}\right)$ led to a diastereomeric ratio (d.r.) 16:1 and an ee of 95\% (Table 2, entry 3). Quantum mechanical calculations have revealed that the side arm has a very important role regarding the asymmetric induction, which is related to the distance of the sodium ion and the crown ring, influenced by the substituent of the nitrogen.

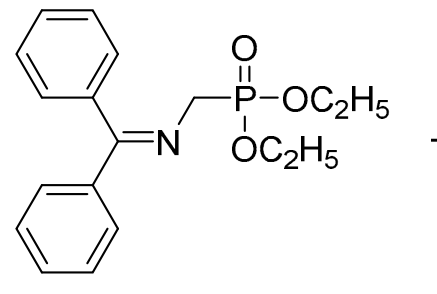

52

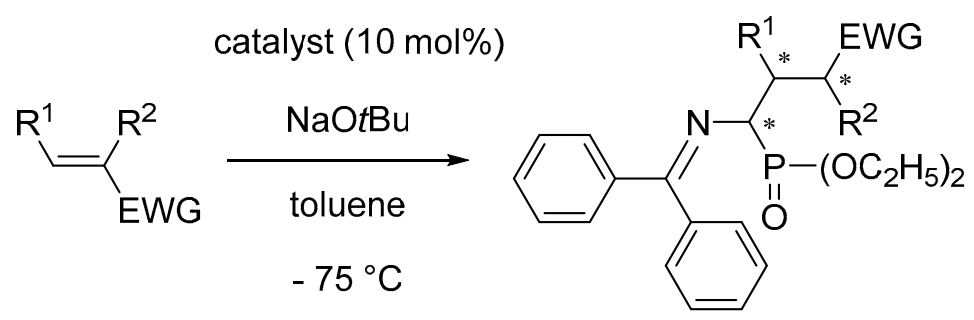

53
54

$$
\mathrm{EWG}=\mathrm{CN}, \mathrm{COOC}_{2} \mathrm{H}_{5}, \mathrm{COOtC}_{4} \mathrm{H}_{9}
$$

Scheme 9. Michael addition of phosphonoglycine derivative 52 to electron deficient olefins (53).

Table 2. Effect of crown ethers in the Michael addition of phosphonoglycine derivative 52 to electron deficient olefins (53).

\begin{tabular}{cccccccc}
\hline Entry & $\mathbf{R}^{\mathbf{1}}$ & $\mathbf{R}^{\mathbf{2}}$ & EWG & Catalyst & Yield, \% & d.r. & ee, \% \\
\hline 1 & $\mathrm{CH}_{3}$ & $\mathrm{H}$ & $\mathrm{CN}$ & $\mathbf{2 3 i}$ & 76 & $6: 1$ & 86 \\
2 & $\mathrm{H}$ & $\mathrm{H}$ & $\mathrm{CN}$ & $\mathbf{2 3 i}$ & 84 & - & 75 \\
3 & $\mathrm{CH}_{3}$ & $\mathrm{H}$ & $\mathrm{CN}$ & $\mathbf{2 3 k}$ & 76 & $16: 1$ & 95 \\
\hline
\end{tabular}

2.2.3. Michael Addition of Cyanofluoromethyl Phosphonate

In collaboration with a research group from the field of organophosphorous chemistry,

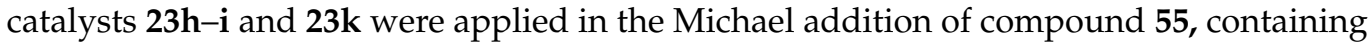


a phosphonic ester moiety, to electron deficient olefins (Scheme 10) [56]. When a nitroolefin $\left(56, \mathrm{EWG}=\mathrm{NO}_{2}\right)$ was reacted with the phosphonate 55, enantioselectivity increased above $80 \%$ ee in the case of lariat ethers $23 \mathbf{i}$ and $23 \mathbf{k}$ (Table 3, entries 1and 2). In addition to the structural motifs of the carbohydrate-based catalyst, i.e., annulation of the ring and substitution of the nitrogen, the substrate also influenced the asymmetric induction.

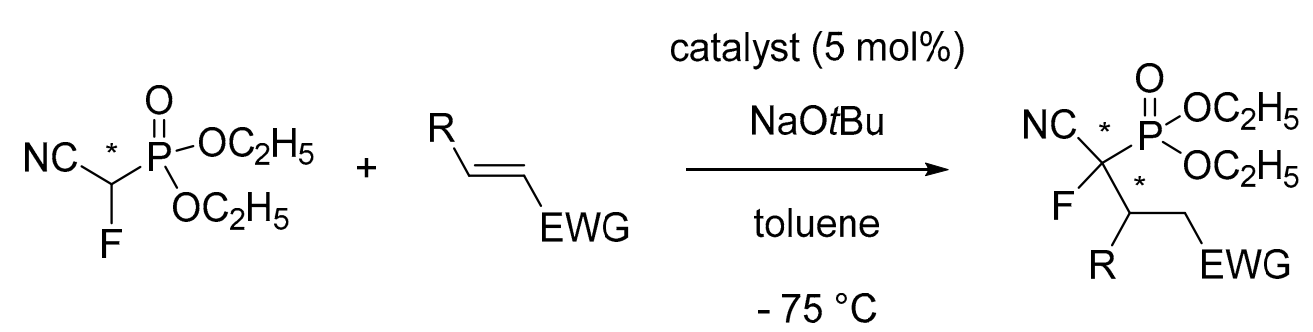

\section{$\mathrm{EWG}=\mathrm{CN}, \mathrm{NO}_{2}, \mathrm{COOCH}_{3}, \mathrm{COOC}_{2} \mathrm{H}_{5}, \mathrm{COOtC}_{4} \mathrm{H}_{9}$}

Scheme 10. Michael addition of diethyl cyanofluoromethyl phosphonate (55) to electron deficient olefins 56.

Table 3. Effect of crown ethers in the Michael addition of diethyl cyanofluoromethyl phosphonate (55) to electron deficient olefins 56.

\begin{tabular}{ccccccc}
\hline Entry & $\mathbf{R}$ & EWG & Catalyst & Yield, $\%$ & d.r. & ee, $\%$ \\
\hline 1 & $\mathrm{C}_{6} \mathrm{H}_{5}$ & $\mathrm{NO}_{2}$ & $\mathbf{2 3 i}$ & 82 & $7: 1$ & 82 \\
2 & $\mathrm{C}_{6} \mathrm{H}_{5}$ & $\mathrm{NO}_{2}$ & $\mathbf{2 3 k}$ & 85 & $6: 1$ & 88 \\
\hline
\end{tabular}

\subsubsection{Michael Addition of Diethyl Acetamidomalonate}

In 2011, another asymmetric Michael addition was reported. Diethyl acetamidomalonate (59) was reacted with $\beta$-nitrostyrene $\left(\mathbf{5 8}, \mathrm{Ar}=\mathrm{C}_{6} \mathrm{H}_{5}\right.$ ) (Scheme 11) using crown ether $20 \mathrm{~h}$ as the phase transfer catalyst. Product $60\left(\mathrm{Ar}=\mathrm{C}_{6} \mathrm{H}_{5}\right)$ was formed in excellent enantiomeric purity (99\% ee) (Table 4, entry 1). Similar results were obtained using 4-chloro$\left(58, \mathrm{Ar}=4-\mathrm{Cl}-\mathrm{C}_{6} \mathrm{H}_{4}\right)$ and 4-nitro- $\beta$-nitrostyrene $\left(58, \mathrm{Ar}=4-\mathrm{O}_{2} \mathrm{~N}-\mathrm{C}_{6} \mathrm{H}_{4}\right)(99 \%$ and $97 \%$, respectively) (Table 4, entries 2 and 3) [57]. Later, the effect of the substituent on the aromatic ring was examined using catalyst 20h. It was found that, except the above-mentioned two examples, in the reactions of substituted nitrostyrenes lower optical purity was observed in the products. When the phenyl group was replaced by another aromatic ring, the asymmetric induction was also weaker [58]. Effect of some glucose-based lariat ethers 20 with different substituents on the nitrogen atom was also systematically investigated. The results proved that the side arm on the nitrogen highly affects the catalytic activity. While macrocycle $20 \mathrm{~h}$ bearing a hydroxypropyl side chain resulted in $99 \%$ optical purity, its methoxypropyl analogue, $20 \mathbf{j}$ gave the product in $38 \%$ ee (Table 4 , entry 4). Elongation of the side arm in the crown ether (20n) led to the formation of a racemic mixture (Table 4 , entry 6). Replacement of the $\mathrm{OH}$ function to a $\mathrm{N}\left(\mathrm{CH}_{3}\right)_{2}$ group (catalyst $20 \mathrm{~m}, 78 \%$ ee generated) (Table 4, entry 5) affected the asymmetric induction unfavorably [26]. Later, the effect of the anomeric substituent of the carbohydrate on the catalytic activity was investigated, glucose-based crown compounds 20h, 41a-b ( $\alpha$-series) and 44a-c ( $\beta$-series) were used as phase transfer catalysts in the Michael addition of $\beta$-nitrostyrene $\left(58, \mathrm{Ar}=\mathrm{C}_{6} \mathrm{H}_{5}\right)$. Altering the alkyl group in the axial position of C-1 (41a-b) or switching to equatorial substitution $(44 a-c)$, the asymmetric induction decreased significantly (e.g., in the case of 41 a to $78 \%$ ee, while using $42 \mathrm{~b}$ led to $68 \%$ ee; Table 4 , entries 14 and 15). 


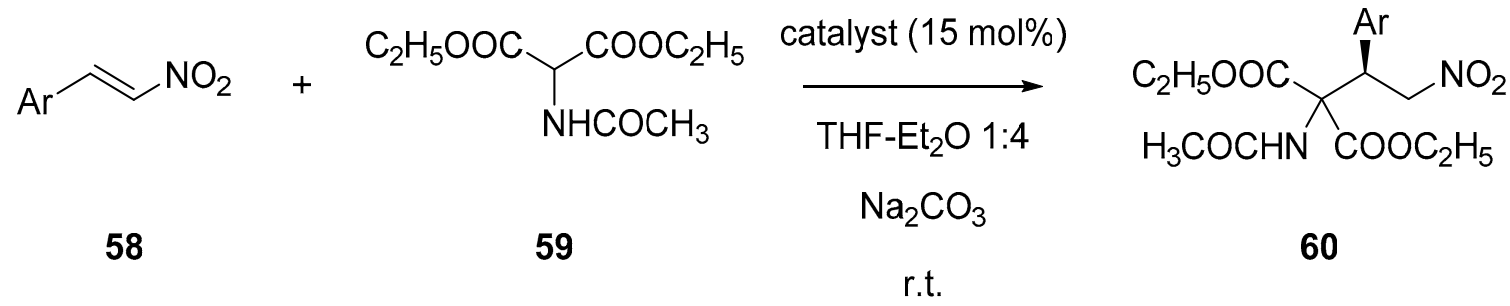

Scheme 11. Michael addition of diethyl acetamidomalonate (59) to nitrostyrenes (58).

Table 4. Effect of crown ethers in the Michael addition of diethyl acetamidomalonate (59) to nitrostyrenes (58).

\begin{tabular}{ccccc}
\hline Entry & $\mathbf{A r}$ & Catalyst & Yield, $\%$ & ee, $\%$ \\
\hline 1 & $\mathrm{C}_{6} \mathrm{H}_{5}$ & $\mathbf{2 0 h}$ & 60 & 99 \\
2 & $4-\mathrm{Cl}_{-}-\mathrm{C}_{6} \mathrm{H}_{4}$ & $\mathbf{2 0 h}$ & 45 & 99 \\
3 & $4-\mathrm{O}_{2} \mathrm{~N}_{-}-\mathrm{C}_{6} \mathrm{H}_{4}$ & $\mathbf{2 0 h}$ & 78 & 97 \\
4 & $\mathrm{C}_{6} \mathrm{H}_{5}$ & $\mathbf{2 0 j}$ & 58 & 38 \\
5 & $\mathrm{C}_{6} \mathrm{H}_{5}$ & $\mathbf{2 0 \mathbf { m }}$ & 30 & 78 \\
6 & $\mathrm{C}_{6} \mathrm{H}_{5}$ & $\mathbf{2 0 n}$ & 38 & 0 \\
7 & $\mathrm{C}_{6} \mathrm{H}_{5}$ & $\mathbf{2 6 d}$ & 90 & 92 \\
8 & $\mathrm{C}_{6} \mathrm{H}_{5}$ & $\mathbf{2 6 f}$ & 30 & 70 \\
9 & $\mathrm{C}_{6} \mathrm{H}_{5}$ & $\mathbf{3 3 c}$ & 50 & 80 \\
10 & $\mathrm{C}_{6} \mathrm{H}_{5}$ & $\mathbf{3 4 c}$ & 59 & 95 \\
11 & $\mathrm{C}_{6} \mathrm{H}_{5}$ & $\mathbf{3 8 c}$ & 65 & 51 \\
12 & $\mathrm{C}_{6} \mathrm{H}_{5}$ & $\mathbf{3 8 d}$ & 22 & 65 \\
13 & $\mathrm{C}_{6} \mathrm{H}_{5}$ & $\mathbf{4 0 a}$ & 57 & 78 \\
14 & $\mathrm{C}_{6} \mathrm{H}_{5}$ & $\mathbf{4 1 a}$ & 67 & 68 \\
15 & $\mathrm{C}_{6} \mathrm{H}_{5}$ & $\mathbf{4 2 b}$ & 71 & \\
\hline
\end{tabular}

Arabinose-based compounds 33a-c generated moderate enantiomeric excess in the Michael addition of acetamidomalonate 59. Using catalyst 33c, the $R$ enantiomer was formed in an ee of $61 \%$ (Table 4, entry 9) [40].

Monoaza-15-crown-5 ethers 34a-d, containing a 2-deoxy-ribo-hexopyranoside moiety, showed poor enantioselectivity in this Michael addition, except for 34c bearing a hydroxypropyl side arm and a methoxyphenyl substituent, which generated higher asymmetric induction ( $80 \%$ ee) (Table 4, entry 10) [41]. Comparison of the results of crown ether $\mathbf{2 0 h}$ derived from glucose and lariat ether 34c synthesized from 2-deoxy-ribo-hexopyranoside suggests that the interaction of the aromatic ring during the reaction is necessary to gain enantioselectivity.

Galactose-based lariat ether $\mathbf{2 6 d}$, which is the C-4 epimer of crown ether $\mathbf{2 0 h}$, proved to be highly effective in this Michael addition ( $92 \%$ ee) (Table 4, entry 7). As it was experienced earlier, using a catalyst bearing a methoxypropyl group, lower enantiomeric excess was measured (26f, 70\%) (Table 4, entry 8) [34].

Among the threitol-based crown compounds, the above-mentioned phenomenon was observed again. The highest enantioselectivity was observed in the case of 1,4-di-O-benzylsubstituted 38c (95\% ee) (Table 4, entry 11), while using its methoxypropyl pair 38c, the asymmetric induction has decreased to $51 \%$ (Table 4, entry 12) [43].

Lariat ethers 27, 39 and $\mathbf{4 0}$ synthesized from mannitol showed only moderate efficiency (14-65\% ee). As it was assumed, ketal groups in the mannitol moiety had an impact on the enantioselectivity; macrocycle 40a bearing cyclohexylidene groups generated the highest ee value (65\%) (Table 4, entry 13) [44].

Xylal- and arabinal-based crown compounds $45-48$ were poorly effective in this reaction (5-34\% ee), regardless of the side arm or the carbohydrate unit [47]. 


\subsubsection{Michael Addition of Diethyl Acetoxymalonate}

Michael addition of chalcones (49) and diethyl acetoxymalonate (61) was also studied in the presence of carbohydrate-based macrocycles (Scheme 12). Using catalyst 20h derived from glucose, excellent enantioselectivity was measured (96\% ee) (Table 5, entry 1) [59,60]. Investigating the substituent effect on the outcome of the reaction revealed that the selectivity of catalyst 20h depends on the substrate. The highest asymmetric induction was observed in the case of 4-nitro-, 4-chloro- and 4-methoxychalcone (89\%, 88\% and 97\% ee, respectively) (Table 5, entries 2-4). Interestingly, when, instead of a phenyl group, a heteroaromatic group (furan-2-yl or thiophen-2-yl) was introduced next to the carbonyl group of the chalcone, the Michael addition resulted in enantiomerically pure products (Table 5, entries 5 and 6) [60].<smiles>O=C(Br)/C=C/[In]</smiles>

49<smiles>CCOC(=O)C(OCC)C(OCC)C(C)=O</smiles>

61

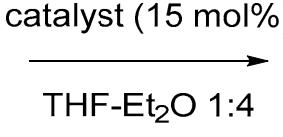

$\mathrm{Na}_{2} \mathrm{CO}_{3}$

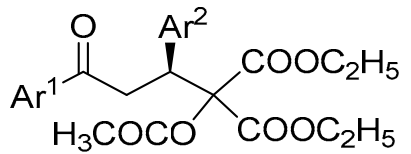

62

r.t.

Scheme 12. Michael addition of chalcones (49) and diethyl acetoxymalonate (61).

Table 5. Effect of crown ethers in the Michael addition of chalcones (49) and diethyl acetoxymalonate (61).

\begin{tabular}{cccccc}
\hline Entry & $\mathbf{A r}^{\mathbf{1}}$ & $\mathbf{A r}^{\mathbf{2}}$ & Catalyst & Yield, \% & ee, \% \\
\hline 1 & $\mathrm{C}_{6} \mathrm{H}_{5}$ & $\mathrm{C}_{6} \mathrm{H}_{5}$ & $\mathbf{2 0 h}$ & 72 & 96 \\
2 & $\mathrm{C}_{6} \mathrm{H}_{5}$ & $4-\mathrm{O}_{2} \mathrm{~N}_{-} \mathrm{C}_{6} \mathrm{H}_{4}$ & $\mathbf{2 0 h}$ & 73 & 89 \\
3 & $\mathrm{C}_{6} \mathrm{H}_{5}$ & $4-\mathrm{Cl}_{6}-\mathrm{C}_{6} \mathrm{H}_{4}$ & $\mathbf{2 0 h}$ & 76 & 88 \\
4 & $\mathrm{C}_{6} \mathrm{H}_{5}$ & $4-\mathrm{H}_{3} \mathrm{CO}-\mathrm{C}_{6} \mathrm{H}_{4}$ & $\mathbf{2 0 h}$ & 73 & 97 \\
5 & Furan-2-yl & $\mathrm{C}_{6} \mathrm{H}_{5}$ & $\mathbf{2 0 h}$ & 75 & 99 \\
6 & Tiophen-2-yl & $\mathrm{C}_{6} \mathrm{H}_{5}$ & $\mathbf{2 0 h}$ & 76 & 99 \\
7 & $\mathrm{C}_{6} \mathrm{H}_{5}$ & $\mathrm{C}_{6} \mathrm{H}_{5}$ & $\mathbf{2 6 d}$ & 58 & 99 \\
8 & $\mathrm{C}_{6} \mathrm{H}_{5}$ & $\mathrm{C}_{6} \mathrm{H}_{5}$ & $\mathbf{2 6 f}$ & 67 & 98 \\
9 & $\mathrm{C}_{6} \mathrm{H}_{5}$ & $4-\mathrm{O}_{2} \mathrm{~N}_{5}-\mathrm{C}_{6} \mathrm{H}_{4}$ & $\mathbf{2 6 d}$ & 55 & 94 \\
10 & $\mathrm{C}_{6} \mathrm{H}_{5}$ & $4-\mathrm{O}_{2} \mathrm{~N}-\mathrm{C}_{6} \mathrm{H}_{4}$ & $\mathbf{2 6 f}$ & 85 & 99 \\
\hline 11 & $\mathrm{C}_{6} \mathrm{H}_{5}$ & $4-\mathrm{H}_{3} \mathrm{CO}-\mathrm{C}_{6} \mathrm{H}_{4}$ & $\mathbf{2 6 d}$ & 69 & 99 \\
12 & $\mathrm{C}_{6} \mathrm{H}_{5}$ & $4-\mathrm{H}_{3} \mathrm{CO}-\mathrm{C}_{6} \mathrm{H}_{4}$ & $\mathbf{2 6 f}$ & 42 & 88 \\
13 & $\mathrm{C}_{6} \mathrm{H}_{5}$ & $\mathrm{C}_{6} \mathrm{H}_{5}$ & $\mathbf{3 8 a}$ & 68 & 96 \\
14 & $\mathrm{C}_{6} \mathrm{H}_{5}$ & $4-\mathrm{Cl}_{6}-\mathrm{C}_{6} \mathrm{H}_{4}$ & $\mathbf{3 8 c}$ & 76 & 99 \\
15 & $\mathrm{C}_{6} \mathrm{H}_{5}$ & $4-\mathrm{H}_{3} \mathrm{CO}-\mathrm{C}_{6} \mathrm{H}_{4}$ & $\mathbf{3 8 e}$ & 33 & 99 \\
\hline
\end{tabular}

In the reaction of acetoxymalonate $\mathbf{6 1}$, lariat ethers $\mathbf{2 6 \mathrm { d }}$ and $\mathbf{2 6 \mathrm { f }}$ containing galactose unit showed high enantioselectivity in many cases. The addition reaction of chalcone (49, $\left.\mathrm{Ar}^{1}=\mathrm{Ar}^{2}=\mathrm{C}_{6} \mathrm{H}_{5}\right)$ resulted in $99 \%$ ee in the presence of $\mathbf{2 6 \mathbf { d }}$ bearing a hydroxypropyl side arm, and $98 \%$ ee using $\mathbf{2 6 f}$ having a methoxypropyl substituent (Table 5, entries 7 and 8 ). Among the substituted products, the 4-nitro and 4-methoxy derivatives were prepared with the highest ee values (in the case of $\mathbf{2 6 d}$ : $94 \%$ and $99 \%$, in the case of $\mathbf{2 6 f :} \mathbf{9 9 \%}$ and 88\%) (Table 5, entries 9-12) [34].

Threitol-based crown compounds generated at least moderate enantioselectivity when different chalcones were used. In the case of chalcone $\left(49, \mathrm{Ar}^{1}=\mathrm{Ar}^{2}=\mathrm{C}_{6} \mathrm{H}_{5}\right)$, lariat ether 38a containing the di-O-methyl threitol moiety was the most effective ( $96 \%$ ee) (Table 5 , entry 13), while catalysts $38 \mathrm{c}$ and 38e yielded the substituted products 62 with the highest ee values (38c: $99 \%$ ee for $62 \mathrm{Ar}^{1}=\mathrm{C}_{6} \mathrm{H}_{5}, \mathrm{Ar}^{2}=4-\mathrm{Cl}_{-} \mathrm{C}_{6} \mathrm{H}_{4} ; 38 \mathrm{e}: 99 \%$ ee for $62 \mathrm{Ar}^{1}=\mathrm{C}_{6} \mathrm{H}_{5}$, $\mathrm{Ar}^{2}=4-\mathrm{H}_{3} \mathrm{CO}-\mathrm{C}_{6} \mathrm{H}_{4}$ ) (Table 5, entries 14 and 15) [43]. 


\subsubsection{MIRC Reaction of Chalcones}

When an electron deficient olefin is reacted with a compound that possesses both a leaving group and an acidic hydrogen on the same carbon atom, is a so-called Michaelinitiated ring closure (MIRC) reaction. Applying chalcones (49) as Michael acceptors, chiral cyclopropane compounds 64 were synthesized with good enantioselectivity (up to $99 \%$ ee) using diethyl bromomalonate (63) (Scheme 13). Only the anti (trans) isomer of 64 could be isolated in all experiments.<smiles>O=C([Al])/C=C/[Te]</smiles>

49<smiles>CCOC(=O)C(Br)C(=O)OCC</smiles>

63

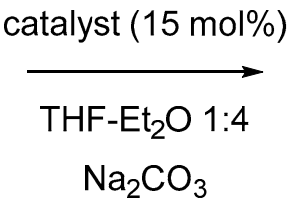

r.t.<smiles>CCOC(=O)[C@H]1[C@H]([17O]CC)C1(C(=O)Br)C(=O)OCC</smiles>

64

Scheme 13. Michael-initiated ring closure (MIRC) reaction of chalcones (61) and diethyl bromomalonate (64).

In the reaction of chalcone $\left(49, \mathrm{Ar}^{1}=\mathrm{Ar}^{2}=\mathrm{C}_{6} \mathrm{H}_{5}\right)$, lariat ether 20h derived from glucose showed good enantioselectivity ( $88 \%$ ee) (Table 6 , entry 1 ). When chalcone analogues were used under the same conditions, the substituents affected the catalytic activity of $\mathbf{2 0 h}$. Except for two compounds (49, $\mathrm{Ar}^{1}=4-\mathrm{O}_{2} \mathrm{~N}-\mathrm{C}_{6} \mathrm{H}_{4}, \mathrm{Ar}^{2}=\mathrm{C}_{6} \mathrm{H}_{5}, 99 \%$ ee and 49, $\mathrm{Ar}^{1}=\mathrm{C}_{6} \mathrm{H}_{5}$, $\mathrm{Ar}^{2}=$ thiophen-2-yl, 94\% ee) enatiomeric excess decreased (Table 6, entries 2 and 3) [59,61].

Table 6. Effect of crown ethers in the MIRC reaction of chalcones (49) and diethyl bromomalonate (63).

\begin{tabular}{cccccc}
\hline Entry & $\mathbf{A r}^{\mathbf{1}}$ & $\mathbf{A r}^{\mathbf{2}}$ & Catalyst & Yield, $\%$ & ee, $\mathbf{\%}$ \\
\hline 1 & $\mathrm{C}_{6} \mathrm{H}_{5}$ & $\mathrm{C}_{6} \mathrm{H}_{5}$ & $\mathbf{2 0 h}$ & 28 & 88 \\
2 & $4-\mathrm{O}_{2} \mathrm{~N}_{-} \mathrm{C}_{6} \mathrm{H}_{4}$ & $\mathrm{C}_{6} \mathrm{H}_{5}$ & $\mathbf{2 0 h}$ & 77 & 99 \\
3 & $\mathrm{C}_{6} \mathrm{H}_{5}$ & Thiophen-2-yl & $\mathbf{2 0 h}$ & 57 & 94 \\
4 & $\mathrm{C}_{6} \mathrm{H}_{5}$ & $\mathrm{C}_{6} \mathrm{H}_{5}$ & $\mathbf{2 6 d}$ & 32 & 98 \\
5 & $\mathrm{C}_{6} \mathrm{H}_{5}$ & $\mathrm{C}_{6} \mathrm{H}_{5}$ & $\mathbf{2 6 f}$ & 35 & 99 \\
6 & $\mathrm{C}_{6} \mathrm{H}_{5}$ & $\mathrm{C}_{6} \mathrm{H}_{5}$ & $\mathbf{3 8 a}$ & 31 & 98 \\
7 & $\mathrm{C}_{6} \mathrm{H}_{5}$ & $\mathrm{C}_{6} \mathrm{H}_{5}$ & $\mathbf{3 8 c}$ & 28 & 99 \\
8 & $\mathrm{C}_{6} \mathrm{H}_{5}$ & $\mathrm{C}_{6} \mathrm{H}_{5}$ & $\mathbf{3 8 e}$ & 33 & 86 \\
\hline
\end{tabular}

Applying methyl $\alpha$-D-galactoside-based crown ethers, both $\mathbf{2 6 d}$ and $\mathbf{2 6 f}$ generated product $64\left(\mathrm{Ar}^{1}=\mathrm{Ar}^{2}=\mathrm{C}_{6} \mathrm{H}_{5}\right)$ in excellent optical purity $(98 \%$ and $99 \%$, respectively) (Table 6, entries 4 and 5) [34].

Lariat ethers 38a, 38c and 38e with a hydroxypropyl side arm and threitol moiety proved to be also outstanding catalysts in this cyclopropanation. Presence of methyl (38a) or benzyl (38c) groups in the sugar unit led to high enantioselectivity $(98 \%$ and $99 \%$, respectively) (Table 6, entries 6 and 7), while using macrocycle 38e containing a 1,4-diO-butyl threitol sub-unit, a somewhat lower enantioselectivity was observed ( $86 \%$ ee) (Table 6, entry 8) [43].

\subsubsection{MIRC Reaction of Arylidenemalononitriles}

To simplify the outcome of the MIRC reaction (i.e., the number of possible isomers), benzylidenemalononitrile $\left(65, \mathrm{Ar}=\mathrm{C}_{6} \mathrm{H}_{5}\right)$ was used to form new cyclopropane derivatives 66 (Scheme 14). Depending on the substituents of the aromatic ring, crown 20h generated enantiomeric excess up to $99 \%[59,61]$. Interestingly, the asymmetric induction generated by catalyst $20 \mathrm{~h}$ was low $\left(32 \%\right.$ ee) when an unsubstituted Michael acceptor $\left(65, \mathrm{Ar}=\mathrm{C}_{6} \mathrm{H}_{5}\right)$ was used (Table 7, entry 1). The best ee values (92\% and 99\%) were obtained in the reaction of 4-methyl- and 3,4-methylenedioxy-substituted benzylidenemalononitrile (65, $\mathrm{Ar}=4-\mathrm{H}_{3} \mathrm{C}-\mathrm{C}_{6} \mathrm{H}_{4}$ and 3,4-methylenedioxy $-\mathrm{C}_{6} \mathrm{H}_{3}$, respectively) (Table 7, entries 2 and 3). 


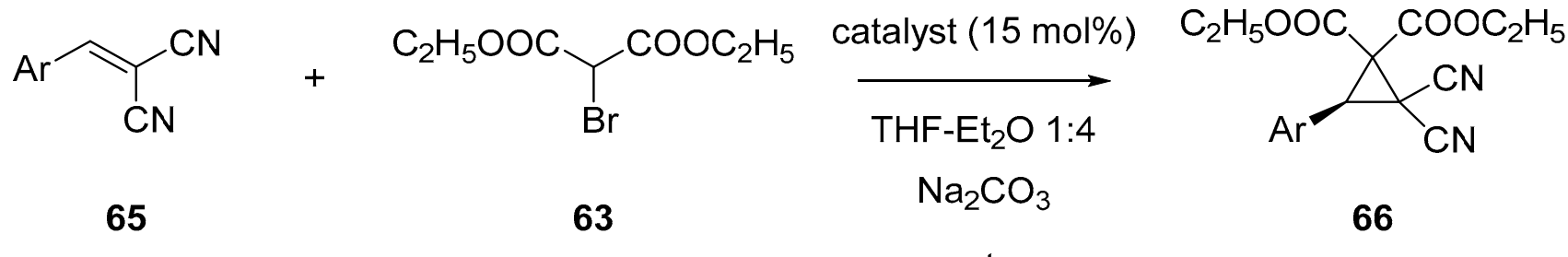

r.t.

Scheme 14. Michael-initiated ring closure reaction of arylidenemalononitriles (65) and diethyl bromomalonate (63).

Table 7. Effect of crown ethers in the MIRC reaction of arylidenemalononitriles (65) and diethyl bromomalonate (63).

\begin{tabular}{ccccc}
\hline Entry & Ar & Catalyst & Yield, $\%$ & ee, $\%$ \\
\hline 1 & $\mathrm{C}_{6} \mathrm{H}_{5}$ & $\mathbf{2 0 h}$ & 82 & 32 \\
2 & $4-\mathrm{H}_{3} \mathrm{C}-\mathrm{C}_{6} \mathrm{H}_{4}$ & $\mathbf{2 0 h}$ & 74 & 92 \\
3 & $3,4-\mathrm{OCH}_{2} \mathrm{O}-\mathrm{C}_{6} \mathrm{H}_{3}$ & $\mathbf{2 0 h}$ & 59 & 99 \\
4 & $\mathrm{C}_{6} \mathrm{H}_{5}$ & $\mathbf{2 6 f}$ & 84 & 78 \\
5 & $4-\mathrm{H}_{3} \mathrm{C}-\mathrm{C}_{6} \mathrm{H}_{4}$ & $\mathbf{2 6 f}$ & 86 & 98 \\
6 & $4-\mathrm{H}_{3} \mathrm{C}-\mathrm{C}_{6} \mathrm{H}_{4}$ & $\mathbf{2 7 e}$ & 81 & 99 \\
7 & $3-\mathrm{H}_{3} \mathrm{C}-\mathrm{C}_{6} \mathrm{H}_{4}$ & $\mathbf{3 8 a}$ & 74 & 99 \\
8 & $4-\mathrm{H}_{3} \mathrm{C}-\mathrm{C}_{6} \mathrm{H}_{4}$ & $\mathbf{3 8 a}$ & 76 & 99 \\
9 & $4-\mathrm{H}_{3} \mathrm{C}-\mathrm{C}_{6} \mathrm{H}_{4}$ & $\mathbf{3 9 a}$ & 70 & 96 \\
10 & $4-\mathrm{H}_{3} \mathrm{C}-\mathrm{C}_{6} \mathrm{H}_{4}$ & $\mathbf{4 0 a}$ & 80 & 98 \\
11 & $4-\mathrm{H}_{3} \mathrm{C}-\mathrm{C}_{6} \mathrm{H}_{4}$ & $\mathbf{4 0 b}$ & 87 & 99 \\
12 & $\mathrm{C}_{6} \mathrm{H}_{5}$ & $\mathbf{4 4 a}$ & 83 & 86 \\
\hline
\end{tabular}

Galactose-based macrocycles proved to be highly efficient in this cyclopropanation. In the presence of crown compound $\mathbf{2 6 f}$, the product $\mathbf{6 6}\left(\mathrm{Ar}=\mathrm{C}_{6} \mathrm{H}_{5}\right)$ was formed in an ee of $78 \%$ (Table 7 , entry 4 ), while using substituted 65 derivatives, the examined ones were mostly obtained with higher enantioselectivity (e.g., in case of $66 \mathrm{Ar}=4-\mathrm{H}_{3} \mathrm{C}-\mathrm{C}_{6} \mathrm{H}_{4}, 98 \%$ ee) (Table 7, entry 5) [34]. Among the $\beta$-series of catalysts prepared from galactose, application of 44a resulted in the highest asymmetric induction ( $86 \%$ ee) (Table 7 , entry 12) [46].

Lariat ethers synthesized from sugar alcohols (mannitol or threitol) showed diverse activity. Mannitol-containing crown ethers 27e, 39a, 40a and 40b gave cyclopropane 66 ( $\mathrm{Ar}$ $\left.=4-\mathrm{H}_{3} \mathrm{C}-\mathrm{C}_{6} \mathrm{H}_{4}\right)$ with excellent enantioselectivity $(99 \%, 96 \%, 98 \%$ and $99 \%$ ee, respectively) (Table 7, entries 6 and 9-11) [44]. Using threitol-based 38a as the catalyst, an ee value of 99\% was achieved in the case of 3-methyl- and 4-methyl-substituted Michael acceptor 66 (Table 7, entries 7 and 8) [43]. In threitol-based compounds 38a-f, the groups attached to the chiral carbon atoms are rather simple, yet the outcome of the reaction is highly influenced by these substituents.

\subsubsection{MIRC Reaction of Arylidene-1,3-Diphenylpropane-1,3-Diones}

Reactions of arylidene-1,3-diphenylpropane-1,3-diones (67) and diethyl bromomalonate (63) resulted in cyclopropane derivatives 68 with only one stereogenic center as well (Scheme 15). Replacement of the nitrile groups to benzoyl functions in the previous reaction, resulted in lower ee values. Glucose-based crown ether $20 \mathrm{~h}$ generated $60 \%$ ee (Table 8 , entry 1). Substitution on the arylidene unit had a negative impact on the enantioselectivity of crown 20h [59,61]. 
<smiles>CCOC(=O)C(Br)C(OCC)C(=O)OCC</smiles>

67
63 r.t.

Scheme 15. Michael-initiated ring closure reaction of arylidene-1,3-diphenylpropane-1,3-diones (67) and diethyl bromomalonate (63).

Table 8. Effect of crown ethers in the MIRC reaction of arylidene-1,3-diphenylpropane-1,3-diones (67) and diethyl bromomalonate (63).

\begin{tabular}{ccccc}
\hline Entry & Ar & Catalyst & Yield, \% & ee, \% \\
\hline 1 & $\mathrm{C}_{6} \mathrm{H}_{5}$ & $\mathbf{2 0 h}$ & 52 & 60 \\
2 & $\mathrm{C}_{6} \mathrm{H}_{5}$ & $\mathbf{2 6 d}$ & 46 & 60 \\
3 & $\mathrm{C}_{6} \mathrm{H}_{5}$ & $\mathbf{2 6 f}$ & 67 & 76 \\
4 & $\mathrm{C}_{6} \mathrm{H}_{5}$ & $\mathbf{2 8 b}$ & 35 & 54 \\
5 & $\mathrm{C}_{6} \mathrm{H}_{5}$ & $\mathbf{3 8 e}$ & 38 & 57 \\
\hline
\end{tabular}

Macrocycle $\mathbf{2 6 d}$, the galactose analogue of $\mathbf{2 0 h}$, showed the same efficiency ( $60 \%$ ee) (Table 8, entry 1), while $\mathbf{2 6 f}$ having a methoxypropyl group instead of hydroxypropyl, generated higher enantioselectivity (76\% ee) (Table 8, entry 3 [34]).

Crown ether $\mathbf{2 8 b}$ derived from mannose and threitol-based catalyst $38 \mathbf{e}$, both containing hydroxypropyl side arm, had similar activity to $20 \mathrm{~h}$ ( $54 \%$ and $57 \%$ ee, respectively) (Table 8, entries 4 and 5) [43,61].

\subsubsection{MIRC Reaction of Arylidene Indane-1,3-Diones}

Cyclopropanation of arylidene indane-1,3-diones (69) (Scheme 16) resulted in chiral compounds $\mathbf{7 0}$ with good enantiomeric excess in the presence of carbohydrate-based crown ethers. When glucopyranoside-based lariat ether $20 \mathrm{~h}$ was used in the reaction of benzylidene indane-1,3-dione $\left(69, \mathrm{Ar}=\mathrm{C}_{6} \mathrm{H}_{5}\right)$, only moderate enantiomeric excess was measured (56\%) (Table 9, entry 1). Altering the substrate to other arylidene derivatives, higher ee values were obtained in general. Presence of a nitro group in each position increased the generated asymmetric induction (70-93\% ee) (Table 9, entries 2-4) [61].<smiles>O=C1C(=C[Br+])C(=O)c2ccccc21</smiles>

69<smiles>CCOC(=O)C(Br)C(=O)OCC</smiles>

63

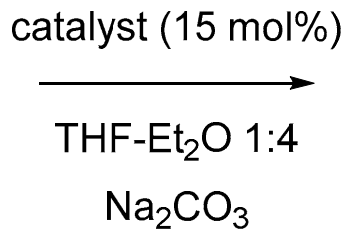

r.t.<smiles>CCOC(=O)C1(C(=O)OCC)C2(C(=O)OCC)C(=O)c3ccccc3C(=O)[C@@]12[Te]</smiles>

70

Scheme 16. Michael-initiated ring closure reaction of arylidene indane-1,3-diones (69) and diethyl bromomalonate (63). 
Table 9. Effect of crown ethers in the MIRC reaction of arylidene indane-1,3-diones (69) and diethyl bromomalonate (63).

\begin{tabular}{ccccc}
\hline Entry & Ar & Catalyst & Yield, $\%$ & ee, $\%$ \\
\hline 1 & $\mathrm{C}_{6} \mathrm{H}_{5}$ & $\mathbf{2 0 h}$ & 33 & 54 \\
2 & $2-\mathrm{H}_{3} \mathrm{C}-\mathrm{C}_{6} \mathrm{H}_{4}$ & $\mathbf{2 0 h}$ & 59 & 79 \\
3 & $3-\mathrm{O}_{2} \mathrm{~N}-\mathrm{C}_{6} \mathrm{H}_{4}$ & $\mathbf{2 0 h}$ & 43 & 70 \\
4 & $4-\mathrm{O}_{2} \mathrm{~N}_{-}-\mathrm{C}_{6} \mathrm{H}_{4}$ & $\mathbf{2 0 h}$ & 83 & 93 \\
5 & $\mathrm{C}_{6} \mathrm{H}_{5}$ & $\mathbf{2 7 e}$ & 72 & 56 \\
6 & $\mathrm{C}_{6} \mathrm{H}_{5}$ & $\mathbf{4 4 a}$ & 77 & 91 \\
7 & $\mathrm{C}_{6} \mathrm{H}_{5}$ & $\mathbf{4 4 b}$ & 76 & 96 \\
8 & $\mathrm{C}_{6} \mathrm{H}_{5}$ & $\mathbf{4 4 c}$ & 71 & 95 \\
\hline
\end{tabular}

Crown ether 27e synthesized from diisopropylidene mannitol showed the same efficiency ( $56 \%$ ee) (Table 9 , entry 5 ) as $20 \mathrm{~h}$ derived from glucose [44].

The highest enantioselectivity was generated by $\beta$-galactoside-based catalysts $44 a$, $44 \mathrm{~b}$ and $44 \mathrm{c}(91 \%, 96 \%$ and $95 \%$ ee, respectively) (Table 9, entries 6-8). As can be seen, the substituent of the anomeric center did not have a significant effect on the selectivity in this MIRC reaction [46].

\subsubsection{MIRC Reaction of Arylidene Cyanosulfones}

Asymmetric cyclopropanation of cyanosulfones $\mathbf{7 1}$ was carried out in the presence of glucose- and galactose-based catalysts (Scheme 17) [27]. Only one of the diastereomers was formed in all cases. Comparing the carbohydrate unit, the catalysts containing a galactoside moiety were slightly more efficient. Among the glucose-containing crown ethers 20q bearing 2-(3,4-dimethoxyphenyl)ethyl substituent on the nitrogen proved to be the most effective (73\% ee) (Table 10, entry 1$)$.<smiles>N#C/C(=C\Br)S(=O)(=O)Oc1ccccc1</smiles>

71<smiles>CCOC(=O)C(Br)C(=O)OCC</smiles>

63

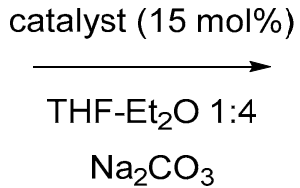

r.t.



72

Scheme 17. Michael-initiated ring closure reaction of arylidene cyanosulfones 71 and diethyl bromomalonate (63).

Table 10. Effect of crown ethers in the MIRC reaction of arylidene cyanosulfones $\mathbf{7 1}$ and diethyl bromomalonate (63).

\begin{tabular}{ccccc}
\hline Entry & Ar & Catalyst & Yield, $\%$ & ee, $\%$ \\
\hline 1 & $\mathrm{C}_{6} \mathrm{H}_{5}$ & $\mathbf{2 0 q}$ & 94 & 73 \\
2 & $3-\mathrm{Cl}_{-}-\mathrm{C}_{6} \mathrm{H}_{4}$ & $\mathbf{2 0 q}$ & 91 & 84 \\
3 & $3-\mathrm{H}_{3} \mathrm{C}-\mathrm{C}_{6} \mathrm{H}_{4}$ & $\mathbf{2 0 q}$ & 90 & 81 \\
4 & $4-\mathrm{O}_{2} \mathrm{~N}_{-}-\mathrm{C}_{6} \mathrm{H}_{4}$ & $\mathbf{2 0 q}$ & 87 & 82 \\
5 & Naphthalen-2-yl & $\mathbf{2 0 q}$ & 92 & 85 \\
6 & $\mathrm{C}_{6} \mathrm{H}_{5}$ & $\mathbf{2 6 g}$ & 95 & 76 \\
7 & $\mathrm{C}_{6} \mathrm{H}_{5}$ & $\mathbf{2 6 h}$ & 93 & 80 \\
8 & $\mathrm{C}_{6} \mathrm{H}_{5}$ & $\mathbf{4 4 g}$ & 90 & 72 \\
\hline
\end{tabular}

Again, the structure of the substrate has a high impact on the enantioselectivity, cyclopropane derivative $72(\mathrm{Ar}=$ naphthalen-2-yl) was formed with highest ee value $(85 \%)$ (Table 10, entry 5). Substituents on the phenyl ring of $\mathbf{7 1}$ in the meta or para position had a positive effect on the asymmetric induction (e.g., 3-chlorophenyl 72: 84\% ee; 3methylphenyl 72: 81\% ee; 4-nitrophenyl 72: 82\% ee) (Table 10, entries 2-4), while orthosubstituted 72 derivatives were obtained as almost racemic mixtures. 
While catalyst $26 \mathrm{~h}$ derived from methyl $\alpha$-D-galactoside gave the best result in the reaction of $71\left(\mathrm{Ar}=\mathrm{C}_{6} \mathrm{H}_{5}\right)(80 \%$ ee) (Table 10, entry 7$)$, its $\beta$-phenyl-galactopyranosidebased analogue $44 \mathrm{~g}$ generated a slightly lower ee value ( $72 \%$ ) (Table 10 , entry 8$)$. In addition to the 2-(3,4-dimethoxyphenyl)ethyl substituent, $\mathbf{2 6}$ g with a 2-(2-methoxyphenyl)ethyl side chain was also effective ( $76 \%$ ee) (Table 10 , entry 6$)$.

\subsubsection{Michael Addition of Methyl Vinyl Ketone}

Itoh and Shirakami investigated the Michael addition of a glycine derivative (73) to methyl vinyl ketone (74) in the presence of glucose-based crown ethers (Scheme 18) [62]. Crown ether 24d inspired the mentioned researchers to investigate the structure-activity relationship of monoaza-15-crown- 5 compounds. Macrocycles 76 and 77 being analogous to $\mathbf{2 4 d}$ were synthesized from methyl 4,6-O-benzylidene-glucopyranoside (19) in 5-7 steps. In crown compound 76, the macro ring is attached to the 3,4 positions of the sugar unit, while in catalyst 77 , the crown and the pyranoside ring is annulated in the 4,6 positions. Comparison the effect of $\mathbf{2 4 d}, \mathbf{7 6}$ and $\mathbf{7 7}$ in the reaction of glycine derivative $\mathbf{7 3}$ and methyl vinyl ketone (74) gave interesting results. Application of $\mathbf{2 4 d}$ as the phase transfer catalyst resulted in the formation of the $S$ enantiomer of $\mathbf{7 5}(72 \%$ ee), while in the presence of $\mathbf{7 6}, R$ antipode was formed in excess (60\% ee). Surprisingly, crown compound 77 was ineffective, a racemic mixture was obtained.

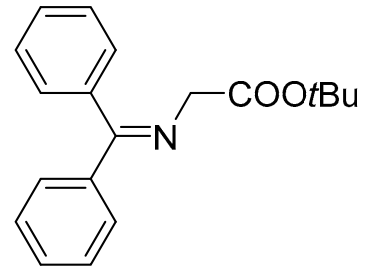

73

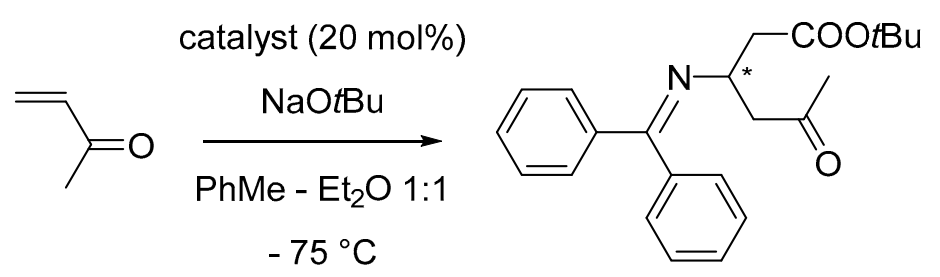

74
75

Scheme 18. Michael addition of glycine derivative 74 to methyl vinyl ketone 75 .<smiles>COC[C@H]1OC(OC)[C@H](OCc2ccccc2)C(OCCOCCNCCOCCO)[C@@H]1C</smiles>

76<smiles>CO[C@H]1O[C@H](COCCOCCNCCOCCO[C@@H]2OCCO[C@H](Cc3ccccc3)[C@@H]2OCc2ccccc2)Cc2ccccc21</smiles>

77

\subsubsection{Darzens Condensations}

Asymmetric Darzens reaction of 2-chloroacetophenone (78, $\left.\mathrm{Ar}^{1}=\mathrm{C}_{6} \mathrm{H}_{5}\right)$ and benzaldehyde $\left(79, \mathrm{Ar}^{2}=\mathrm{C}_{6} \mathrm{H}_{5}\right)$ was first investigated in the presence of glucose-based azacrown ethers 20a-g in 1997 (Scheme 19). Catalyst 20g bearing a hydroxyethyl chain showed moderate enantioselectivity ( $42 \%$ ) (Table 11, entry 1 ), which could be increased by lowering the temperature of the reaction to $-22{ }^{\circ} \mathrm{C}$. The synthesis was diastereoselective, only the formation of the anti (trans) product 80 was observed [50]. Replacement of the hydroxyethyl moiety in compound $\mathbf{2 0} \mathrm{g}$ to a hydroxypropyl group led to increased enantiomeric excess (20h, 62\% ee) (Table 11, entry 2) [24]. The presence of the free hydroxyl group in the side chain proved to be crucial, when crown ethers bearing a propyl chain with different functional groups at the end were tested. Methylation (20j), elongation (20n), and changing 
to dimethylamino $(\mathbf{2 0 m})$ or phenylthiocarbamido (20o) groups led to a significant decrease in enantioselectivity [26].

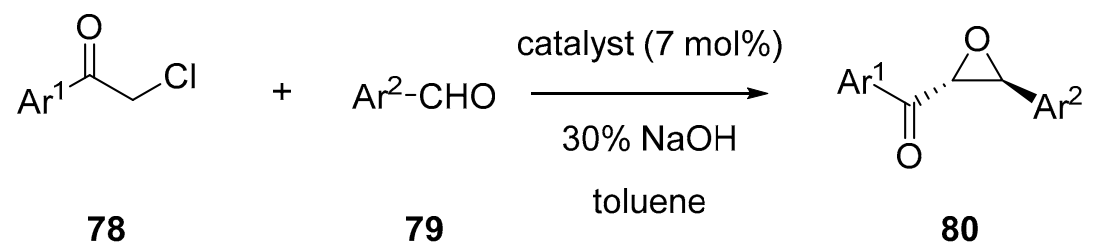

Scheme 19. Darzens condensation of aromatic 2-chloroketones (78) and benzaldehydes (79).

Table 11. Effect of crown ethers in the Darzens condensation of aromatic 2-chloroketones (78) and benzaldehydes (79).

\begin{tabular}{|c|c|c|c|c|c|c|}
\hline Entry & $A r^{1}$ & $A r^{2}$ & Catalyst & Temp., ${ }^{\circ} \mathrm{C}$ & Yield, \% & ee, $\%$ \\
\hline 1 & $\mathrm{C}_{6} \mathrm{H}_{5}$ & $\mathrm{C}_{6} \mathrm{H}_{5}$ & $20 \mathrm{~g}$ & 22 & 93 & 42 \\
\hline 2 & $\mathrm{C}_{6} \mathrm{H}_{5}$ & $\mathrm{C}_{6} \mathrm{H}_{5}$ & $20 \mathrm{~h}$ & 22 & 74 & 62 \\
\hline 3 & Furan-2-yl & $\mathrm{C}_{6} \mathrm{H}_{5}$ & $20 \mathrm{~h}$ & -5 & 55 & 54 \\
\hline 4 & Furan-2-yl & $2-\mathrm{Cl}-\mathrm{C}_{6} \mathrm{H}_{4}$ & $20 \mathrm{~h}$ & -5 & 77 & 70 \\
\hline 5 & Thiophen-2-yl & $\mathrm{C}_{6} \mathrm{H}_{5}$ & $20 \mathrm{~h}$ & -5 & 63 & 71 \\
\hline 6 & Thiophen-2-yl & $3,4-\mathrm{OCH}_{2} \mathrm{O}-\mathrm{C}_{6} \mathrm{H}_{3}$ & $20 \mathrm{~h}$ & -5 & 57 & 86 \\
\hline 7 & Thiophen-3-yl & $\mathrm{C}_{6} \mathrm{H}_{5}$ & $20 \mathrm{~h}$ & -5 & 53 & 52 \\
\hline 8 & Pyrrol-2-yl & $\mathrm{C}_{6} \mathrm{H}_{5}$ & $20 \mathrm{~h}$ & -5 & 33 & 36 \\
\hline 9 & 1-Methyl-pyrrol-2-yl & $\mathrm{C}_{6} \mathrm{H}_{5}$ & $20 \mathrm{~h}$ & -5 & 72 & 16 \\
\hline 10 & 4-Phenyl- $\mathrm{C}_{6} \mathrm{H}_{4}$ & $\mathrm{C}_{6} \mathrm{H}_{5}$ & $20 \mathrm{~h}$ & 20 & 54 & 96 \\
\hline 11 & $\mathrm{C}_{6} \mathrm{H}_{5}$ & $\mathrm{C}_{6} \mathrm{H}_{5}$ & $23 \mathrm{~g}$ & 22 & 68 & 74 \\
\hline 12 & $\mathrm{C}_{6} \mathrm{H}_{5}$ & $\mathrm{C}_{6} \mathrm{H}_{5}$ & $26 d$ & 22 & 81 & 28 \\
\hline 13 & $\mathrm{C}_{6} \mathrm{H}_{5}$ & $\mathrm{C}_{6} \mathrm{H}_{5}$ & $30 a$ & 22 & 75 & 48 \\
\hline 14 & $\mathrm{C}_{6} \mathrm{H}_{5}$ & $\mathrm{C}_{6} \mathrm{H}_{5}$ & $40 a$ & 22 & 57 & 62 \\
\hline 15 & $\mathrm{C}_{6} \mathrm{H}_{5}$ & $\mathrm{C}_{6} \mathrm{H}_{5}$ & $41 a$ & 22 & 94 & 73 \\
\hline 16 & $\mathrm{C}_{6} \mathrm{H}_{5}$ & $\mathrm{C}_{6} \mathrm{H}_{5}$ & $44 d$ & 22 & 81 & 64 \\
\hline 17 & $\mathrm{C}_{6} \mathrm{H}_{5}$ & $\mathrm{C}_{6} \mathrm{H}_{5}$ & $45 a$ & 0 & 65 & 77 \\
\hline 18 & $\mathrm{C}_{6} \mathrm{H}_{5}$ & $\mathrm{C}_{6} \mathrm{H}_{5}$ & 46 & 0 & 61 & 72 \\
\hline
\end{tabular}

Altering the protective group in the 4,6 position of the carbohydrate influenced the catalytic activity of glucose-based crown ethers negatively (e.g., catalyst 30a bearing a naphthylidene moiety gave product $80\left(\mathrm{Ar}^{1}=\mathrm{Ar}^{2}=\mathrm{C}_{6} \mathrm{H}_{5}\right)$ in an ee of $48 \%$ under the same conditions) (Table 11, entry 13) [39].

The substituent in the anomeric position of glucose had only a small impact on the enantioselectivity. When the alkoxy group was in the axial position ( $\alpha$-series), slightly higher ee values were measured than in the case of $\beta$-substituted derivatives. The best result was obtained in the reaction 2-chloroacetophenone (78, $\left.\mathrm{Ar}^{1}=\mathrm{C}_{6} \mathrm{H}_{5}\right)$ and benzaldehyde (79, $\mathrm{Ar}^{2}=\mathrm{C}_{6} \mathrm{H}_{5}$ ) by using crown ether 41a (73\% ee) (Table 11, entry 15) [45].

Heteroaromatic chloroketones were synthesized and then investigated in Darzens condensation with aromatic aldehydes in the presence of crown ether $\mathbf{2 0 h}[57,63]$. The temperature of the reactions was lowered to $-5{ }^{\circ} \mathrm{C}$ to reach higher enantiomeric excess. When 2-chloroacetylfuran (78, $\mathrm{Ar}^{1}=$ furan-2-yl) and benzaldehyde was reacted $\left(79, \mathrm{Ar}^{2}=\mathrm{C}_{6} \mathrm{H}_{5}\right)$, moderate asymmetric induction was observed (54\% ee) (Table 11, entry 3) (Scheme 19). Using substituted benzaldehydes, in general, the ee values were higher (e.g., 80 with $\mathrm{Ar}^{1}=$ furan-2-yl, $\mathrm{Ar}^{2}=2-\mathrm{Cl}-\mathrm{C}_{6} \mathrm{H}_{4}: 70 \%$ ee) (Table 11, entry 4). An inverse trend was observed for 2-chloracetylthiophene (78, $\mathrm{Ar}^{1}=$ thiophen-2-yl). In this case, a substituent on the aldehyde lowered the enantioselectivity, with one exception (80 with $\mathrm{Ar}^{1}=$ thiophen-2-yl, $\mathrm{Ar}^{2}=\mathrm{C}_{6} \mathrm{H}_{5}: 70 \%$ ee; 80 with $\mathrm{Ar}^{1}=$ thiophen-2-yl, $\mathrm{Ar}^{2}=3,4-$ methylenedioxy- $\mathrm{C}_{6} \mathrm{H}_{3}: 86 \%$ ee) (Table 11, entries 5 and 6). Moving the chloroacetyl group to the 3 position of the thiophene ring (78, $\mathrm{Ar}^{1}=$ thiophen-3-yl) led to lower optical purity (52\% ee) (Table 11, entry 7). When pyrrol or 1-methylpyrrol analogues were reacted with benzaldehyde, the selectivity of $\mathbf{2 0 h}$ was weak (80 with $\mathrm{Ar}^{1}=$ pyrrol-2-yl, $\mathrm{Ar}^{2}=\mathrm{C}_{6} \mathrm{H}_{5}$ : 36\% ee; 80 with $\mathrm{Ar}^{1}=1$-methylpyrrol-2-yl, $\mathrm{Ar}^{2}=3,4$ - methylenedioxy- $\mathrm{C}_{6} \mathrm{H}_{3}: 16 \%$ ee) (Table 11 , entries 8 and 9). 
The highest enantioselectivity was reached when $4^{\prime}$-phenyl-2-chloroacetophenon was reacted with benzaldehyde using glucose-based lariat ether 20h (product 80 with $\mathrm{Ar}^{1}=4$-phenyl- $\mathrm{C}_{6} \mathrm{H}_{4}, \mathrm{Ar}^{2}=\mathrm{C}_{6} \mathrm{H}_{5}: 96 \%$ ee) (Table 11, entry 10) (Scheme 19). With other aromatic aldehydes, lower ee values were measured [64].

Investigation of the efficiency of lariat ethers $\mathbf{2 3} \mathbf{a}-\mathbf{h}$, which contain a $\beta$-phenyl glucoside unit, demonstrated again that the side chain has a significant impact on the asymmetric induction. While catalysts $\mathbf{2 3 a - d}$ with a hydrocarbon substituent on the nitrogen atom were ineffective (4-12\% ee), using $\mathbf{2 3} \mathrm{g}$ with a hydroxypropyl group, $74 \%$ ee was measured (Table 11, entry 11) [28,29].

Experiments with galactose-containing macrocycles had similar results. Catalyst 26d with a hydroxypropyl side arm and a $\alpha$-methyl group was inferior (26\% ee) (Table 11 , entry 12 ) to crown compound $\mathbf{4 4 d}$, which have the same side arm, but a $\beta$-phenyl group in C-1 (73\% ee) (Table 11, entry 16) [46].

In the case of mannitol-based crown compounds, it was found again that in addition to the side arm, the protecting group also influenced the generated enantioselectivity. With the exception of compound 40a with cyclohexylidene moiety (62\% ee) (Table 11, entry 14), low ee values were measured in the Darzens reaction [44].

When the effect of xylal- and arabinal-based crown ethers 45-48 were compared, catalysts $47 \mathrm{a}, \mathbf{4 7 b}$ and 48 derived from L- and D-arabinal were ineffective. Application of crown ethers $45 \mathbf{a}$ and $46 \mathbf{a}$, which are mirror images of each other, resulted in good enantiomeric excess (77\% and 72\%, respectively) (Table 11, entries 17 and 18) [47].

In addition to 2-chloroacetyl derivatives, cyclic chloroketones were also applied in Darzens condensations in the presence of lariat ether 20h containing glucose (Scheme 20). In the reaction of 2-chloroindanone $(81, n=0)$ with benzaldehyde $\left(79, \mathrm{Ar}^{2}=\mathrm{C}_{6} \mathrm{H}_{5}\right), 65 \%$ ee was obtained (Table 12, entry 1). In the case of substituted aromatic aldehydes, no clear tendency was observed. The best selectivity was $85 \%$ ee $\left(79, \mathrm{Ar}^{2}=2-\mathrm{Cl}-\mathrm{C}_{6} \mathrm{H}_{4}\right)(\mathrm{Table} 12$, entry 2). When 2-chlorotetralone $(\mathbf{8 1}, n=1)$ was tested, the highest ee value was $74 \%$ in the product $82\left(\mathrm{Ar}=\mathrm{C}_{6} \mathrm{H}_{5}\right)$ (Table 12, entry 3$)$. Any changes on the aromatic part of the aldehyde decreased the measured optical purity [64].<smiles>CC1([Al])CC(Cl)C(=O)c2ccccc21</smiles>

81<smiles>CC1(C)CCCCC12OC21Cc2ccccc2C1=O</smiles>

82

Scheme 20. Darzens condensation of 2-chloroindanone (81, $n=0)$, and of 2-chlorotetralone (81, $n=1)$.

Table 12. Effect of crown ethers in the Darzens condensation of 2-chloroindanone $(\mathbf{8 1}, n=0)$, and of 2-chlorotetralone $(81, n=1)$.

\begin{tabular}{ccccccc}
\hline Entry & $\boldsymbol{n}$ & Ar & Catalyst & Temp., ${ }^{\circ} \mathbf{C}$ & Yield, $\%$ & ee, $\%$ \\
\hline 1 & 0 & $\mathrm{C}_{6} \mathrm{H}_{5}$ & $\mathbf{2 0 h}$ & 0 & 59 & 65 \\
2 & 0 & $2-\mathrm{Cl}_{6} \mathrm{C}_{6} \mathrm{H}_{4}$ & $\mathbf{2 0 h}$ & 0 & 52 & 85 \\
3 & 1 & $\mathrm{C}_{6} \mathrm{H}_{5}$ & $\mathbf{2 0 h}$ & -10 & 84 & 74 \\
\hline
\end{tabular}

\subsubsection{Epoxidations}

Asymmetric epoxidation of chalcone (49, $\mathrm{Ar}^{1}=\mathrm{Ar}^{2}=\mathrm{C}_{6} \mathrm{H}_{5}$ ) was first investigated using glucose- and mannose-based catalysts (Scheme 21) [36]. While screening the side arms, it was found that a free hydroxyl group is required to gain good enantioselectivity. The reaction was diastereoselective, only the anti (trans) isomer could be isolated. Catalyst 
$20 \mathrm{~g}$ with a hydroxyethyl group generated $81 \%$ ee (Table 13, entry 1 ), while lariat ether $20 \mathrm{~h}$ bearing a hydroxypropyl moiety showed even higher efficiency $(92 \%$ ee) (Table 13 , entry 2). Similar results were experienced in the case of mannose-based crown ethers, compounds $\mathbf{2 8} \mathbf{a}$ and $\mathbf{2 8 b}$ proved to be the most efficient ( $72 \%$ and $80 \%$ ee, respectively) (Table 13, entries 9 and 10). It is interesting, that catalysts derived from mannose preferred the formation of the $2 S, 3 R$ enantiomer, while $2 R, 3 S$ antipode was in excess in the case of glucose-based catalysts. It is worth to mention that glucose and mannose differs only in the configuration of $\mathrm{C}-2$, therefore in the case of glucose, anti-annulation can be observed between the monosaccharide and the crown ring, while in the case of mannose, there is a syn-annulation. This difference can be the reason why different enantiomers are formed during the epoxidation reaction.

\section{tBuOOH}<smiles>O=C(Br)/C=C/[Te]</smiles>

49

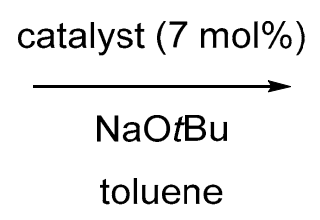

toluene<smiles>O=C([Al])[C@@H]1OC1[Al]</smiles>

80

Scheme 21. Liquid-liquid two phase epoxidation of chalcones (49).

Table 13. Effect of crown ethers in the epoxidation of chalcones (49).

\begin{tabular}{|c|c|c|c|c|c|c|}
\hline Entry & $A r^{1}$ & $\mathrm{Ar}^{2}$ & Catalyst & Temp., ${ }^{\circ} \mathrm{C}$ & Yield, \% & ee, $\%$ \\
\hline 1 & $\mathrm{C}_{6} \mathrm{H}_{5}$ & $\mathrm{C}_{6} \mathrm{H}_{5}$ & $20 \mathrm{~g}$ & 5 & 65 & 81 \\
\hline 2 & $\mathrm{C}_{6} \mathrm{H}_{5}$ & $\mathrm{C}_{6} \mathrm{H}_{5}$ & $20 \mathrm{~h}$ & 5 & 82 & 92 \\
\hline 3 & $4-\mathrm{Cl}-\mathrm{C}_{6} \mathrm{H}_{4}$ & $\mathrm{C}_{6} \mathrm{H}_{5}$ & $20 \mathrm{~h}$ & 0 & 71 & 97 \\
\hline 4 & $3-\mathrm{O}_{2} \mathrm{~N}-\mathrm{C}_{6} \mathrm{H}_{4}$ & $\mathrm{C}_{6} \mathrm{H}_{5}$ & $20 \mathrm{~h}$ & 0 & 55 & 99 \\
\hline 5 & $\mathrm{C}_{6} \mathrm{H}_{5}$ & $2,4-$ di-Cl- $\mathrm{C}_{6} \mathrm{H}_{3}$ & $20 \mathrm{~h}$ & 0 & 50 & 99 \\
\hline 6 & 1-Methylpyrrol-2-yl & $\mathrm{C}_{6} \mathrm{H}_{5}$ & $20 \mathrm{~h}$ & -5 & 80 & 79 \\
\hline 7 & $\mathrm{C}_{6} \mathrm{H}_{5}$ & $\mathrm{C}_{6} \mathrm{H}_{5}$ & $23 g$ & 20 & 51 & 76 \\
\hline 8 & $\mathrm{C}_{6} \mathrm{H}_{5}$ & $\mathrm{C}_{6} \mathrm{H}_{5}$ & $26 d$ & 20 & 35 & 53 \\
\hline 9 & $\mathrm{C}_{6} \mathrm{H}_{5}$ & $\mathrm{C}_{6} \mathrm{H}_{5}$ & $28 a$ & 5 & 70 & $72(2 S, 3 R)$ \\
\hline 10 & $\mathrm{C}_{6} \mathrm{H}_{5}$ & $\mathrm{C}_{6} \mathrm{H}_{5}$ & $28 b$ & 5 & 72 & $80(2 S, 3 R)$ \\
\hline 11 & $\mathrm{C}_{6} \mathrm{H}_{5}$ & $\mathrm{C}_{6} \mathrm{H}_{5}$ & 29 & 5 & 51 & 5 \\
\hline 12 & $\mathrm{C}_{6} \mathrm{H}_{5}$ & $\mathrm{C}_{6} \mathrm{H}_{5}$ & $30 \mathrm{a}$ & 0 & 46 & 89 \\
\hline 13 & $\mathrm{C}_{6} \mathrm{H}_{5}$ & $\mathrm{C}_{6} \mathrm{H}_{5}$ & $31 a$ & 0 & 59 & 67 \\
\hline 14 & $\mathrm{C}_{6} \mathrm{H}_{5}$ & $\mathrm{C}_{6} \mathrm{H}_{5}$ & $41 a$ & 20 & 96 & 94 \\
\hline 15 & $\mathrm{C}_{6} \mathrm{H}_{5}$ & $\mathrm{C}_{6} \mathrm{H}_{5}$ & $41 b$ & 20 & 93 & 93 \\
\hline 16 & $\mathrm{C}_{6} \mathrm{H}_{5}$ & $\mathrm{C}_{6} \mathrm{H}_{5}$ & $42 a$ & 20 & 87 & 84 \\
\hline 17 & $\mathrm{C}_{6} \mathrm{H}_{5}$ & $\mathrm{C}_{6} \mathrm{H}_{5}$ & $44 a$ & 20 & 71 & 59 \\
\hline 18 & $\mathrm{C}_{6} \mathrm{H}_{5}$ & $\mathrm{C}_{6} \mathrm{H}_{5}$ & $44 d$ & 20 & 81 & 64 \\
\hline 19 & $\mathrm{C}_{6} \mathrm{H}_{5}$ & $\mathrm{C}_{6} \mathrm{H}_{5}$ & $45 a$ & 0 & 65 & $77(2 S, 3 R)$ \\
\hline 20 & $\mathrm{C}_{6} \mathrm{H}_{5}$ & Naphthalen-2-yl & $45 a$ & 0 & 72 & $96(2 S, 3 R)$ \\
\hline 21 & $\mathrm{C}_{6} \mathrm{H}_{5}$ & $\mathrm{C}_{6} \mathrm{H}_{5}$ & 46 & 0 & 61 & 72 \\
\hline
\end{tabular}

Comparison of the effect of catalysts containing a methyl glucoside (20h), a methyl mannoside (28b) and a methyl altroside (29) moiety in the epoxidation reaction was carried out not only with chemical experiments but using molecular modeling as well [38]. Crown compound 29 was ineffective regarding the asymmetric induction (Table 13, entry 11). This is, in fact, very interesting; because of the anti-annulation of the carbohydrate unit and the macro ring, catalyst 29 was expected to be effective, but as the results of the in silico experiments revealed, that the annulation is only one of the factors that affect the enantioselectivity.

Comparing the effect of the protecting group in glucose-based crown ethers, macrocycle $20 \mathrm{~h}$ with a benzylidene group was the most effective (92\% ee) (Table 13, entry 2$)$, in 
the case of a naphthylidene unit (30a) the enantioselectivity was almost the same (89\% ee) (Table 13, entry 12), but when an isopropylidene moiety (31a) was in the 4,6 position, the measured ee value decreased to $67 \%$ (Table 13, entry 13) [39].

The anomeric position also had an impact on the asymmetric induction. Selectivity of the $\alpha$-alkyl analogues of $20 \mathrm{~h}$ was retained (41a: $94 \%$ ee; $41 \mathrm{~b}$ : $93 \%$ ee) (Table 13 , entries 14 and 15), while catalysts of the $\beta$-series were less selective (e.g., 42a: $84 \%$ ee) (Table 13, entry 16) [45]. Crown ether $\mathbf{2 3 g}$ containing a phenoxy group in equatorial position also generated lower enantioselectivity ( $76 \%$ ee) (Table 13, entry 7) than macrocycle $20 \mathrm{~h}$ [33].

Alteration on the anomeric center led to different ee values in the case of galactosebased crown ethers. The enantioselectivity was higher when the substituent of C-1 was equatorial. While catalyst $\mathbf{2 6 \mathrm { d }}$ derived from methyl $\alpha$-D-galactoside, which is analogous to glucose-based $20 \mathbf{h}$, generated an ee of $53 \%$ (Table 13, entry 8 ), using its $\beta$-analogue 44a led to a slightly higher enantiomeric excess (59\%) (Table 13, entry 17). In case of catalyst $44 \mathrm{~d}$ bearing a $\beta$-phenyl group, the epoxidation of chalcone (49, $\left.\mathrm{Ar}^{1}=\mathrm{C}_{6} \mathrm{H}_{5}, \mathrm{Ar}^{2}=\mathrm{C}_{6} \mathrm{H}_{5}\right)$, resulted in $64 \%$ ee (Table 13, entry 18) [46].

The structure of the substrate influenced the outcome of the epoxidation as well. Crown ether 20h showed high enantioselectivity, when 4'-chloro- $\left(49, \mathrm{Ar}^{1}=4-\mathrm{Cl}^{\prime} \mathrm{C}_{6} \mathrm{H}_{4}\right.$, $\left.\mathrm{Ar}^{2}=\mathrm{C}_{6} \mathrm{H}_{5}\right), 3^{\prime}$-nitro- $\left(49, \mathrm{Ar}^{1}=3-\mathrm{O}_{2} \mathrm{~N}-\mathrm{C}_{6} \mathrm{H}_{4}, \mathrm{Ar}^{2}=\mathrm{C}_{6} \mathrm{H}_{5}\right)$ or 2,4-dichlorochalcone (49, $\left.\mathrm{Ar}^{1}=\mathrm{C}_{6} \mathrm{H}_{5}, \mathrm{Ar}^{2}=2,4-\mathrm{di}-\mathrm{Cl}-\mathrm{C}_{6} \mathrm{H}_{4}\right)$ was used $(97 \%, 99 \%$ and $99 \%$ ee, respectively) (Table 13, entries 3-5) [65]. In case of unsaturated ketones containing a 1-methylpyrrol subunit, lariat ether $\mathbf{2 0 h}$ generated good enantiomeric excess (e.g., $79 \%$ ee in case of $\mathbf{6 1}$, $\mathrm{Ar}^{1}=1$-methylpyrrol-2-yl, $\mathrm{Ar}^{2}=\mathrm{C}_{6} \mathrm{H}_{5}$ ) (Table 13, entry 6) [63] .

From crown ethers $\mathbf{4 5 - 4 8}$ containing unsaturated carbohydrate units, only the xylalbased $45 \mathrm{a}$ and 46 resulted in an optically active product 80 . While catalyst $45 \mathrm{a}$ derived from D-xylal generated the $2 \mathrm{~S}, 3 \mathrm{R}$ enantiomer of $\mathbf{8 0}\left(\mathrm{Ar}^{1}=\mathrm{C}_{6} \mathrm{H}_{5}, \mathrm{Ar}^{2}=\mathrm{C}_{6} \mathrm{H}_{5}\right)$ with $77 \%$ ee, application of crown ether $\mathbf{4 6}$ synthesized from L-xylal led to the formation of the $2 R, 3 S$ antipode in an ee value of $72 \%$ ee (Table 13, entries 19 and 21). Using chalcone analogues, various enantiomeric excess was observed in the presence of lariat ether 45a. The best selectivity was obtained in the case of compound $\mathbf{8 0}\left(\mathrm{Ar}^{1}=\mathrm{C}_{6} \mathrm{H}_{5}, \mathrm{Ar}^{2}=\right.$ naphthalen-2-yl) (96\% ee) (Table 13, entry 20) [47].

\section{Conclusions}

A variety of chiral crown ethers containing one or two sugar units in annulation with the macrocyclic ring have been synthesized from monosaccharides (such as D-glucose, D-mannose, D-galactose, D-altrose, L-arabinose, etc.) and sugar alcohols (L-threitol, Dmannitol). These chiral macrocycles were tested as phase transfer catalysts in asymmetric reactions (in liquid-liquid and solid-liquid phase systems). A few representatives of the monosaccharide-based crown ethers induced a considerable asymmetric induction in certain reactions. It turned out, that there is no universally applicable catalyst for each reaction, viz. in each asymmetric reaction, different catalysts showed the best results. It was found that the type of the carbohydrate, the substituents on the sugar unit and on the nitrogen atom of the crown ring (side arms) have significant influence on both the chemical yield and the enantioselectivity.

Based on the experiments, monoaza-15-crown-5 lariat ethers incorporating a D-glucose, or a D-galactose moiety proved to be the most efficient catalysts. Sugar-based catalysts with a $\left(\mathrm{CH}_{2}\right)_{3} \mathrm{OH}$ substituent on the nitrogen atom resulted in the best enantioselectivity in the liquid-liquid phase reactions. In solid-liquid reactions, $\left(\mathrm{CH}_{2}\right)_{3} \mathrm{OCH}_{3}$ and 2-(3,4dimethoxyphenyl)ethyl groups also enhanced the asymmetric induction.

Development of novel catalysts is of practical importance, as the lariat ethers can be utilized in phase transfer catalytic reactions, a part of which is to be explored.

The chiral compounds synthesized using carbohydrate-based catalysts are important intermediates in the chemical industry. 
Funding: This research received no external funding.

Conflicts of Interest: The authors declare no conflict of interest.

\section{References}

1. Cram, D.J.; Sogah, G.D.Y.J. Chiral crown complexes catalyse Michael addition reactions to give adducts in high optical yields. Chem. Soc. Chem. Commun. 1981, 625-628. [CrossRef]

2. O'Donell, M.J. Asymmetric phase-transfer reactions. In Catalytic Asymmetric Synthesis, 2nd ed.; Ojima, I., Ed.; Wiley-VCH: New York, NY, USA, 2000; pp. 727-755. [CrossRef]

3. Marouka, K. Asymmetric Phase Transfer Catalysis; Wiley-VCH Verlag GmbH \& Co. KgaA: Weinheim, Germany, 2008. [CrossRef]

4. Soddart, J.F. Chiral crown ethers. In Topics in Stereochemistry; Eliel, E.L., Wilen, S.H., Eds.; John Wiley \& Sons: New York, NY, USA, 1987; Volume 17, pp. 207-288. [CrossRef]

5. Alonso-Lopez, M.; Martin-Lomas, M.; Penadés, S. Asymmetric Michael reaction using macrocyclic lactose derivatives as chiral catalysts. Tetrahedron Lett. 1986, 27, 3551-3554. [CrossRef]

6. Dehmlow, E.V.; Sauerbier, C. Enantioselektive Phasentransfer-Katalyse durch optisch aktive Kronenether. Liebigs Annalen Chemie 1989, 181-185. [CrossRef]

7. Vicent, C.; Martin-Lomas, M.; Penades, S. New synthetic strategy to highly symmetric chiral macrocycles from carbohydrate derivatives. Tetrahedron 1989, 45, 3605-3612. [CrossRef]

8. Van Maarschalkerwaart, D.A.H.; Willard, N.P.; Pandit, U.K. Synthesis of carbohydrate containing crown ethers and their application as catalysts in asymmetric Michael additions. Tetrahedron 1992, 48, 8825-8840. [CrossRef]

9. Pietraszkiewicz, M.; Jurczak, J. Synthesis of chiral diaza-crown ethers incorporating carbohydrate units. Tetrahedron 1984, 40, 2967-2970. [CrossRef]

10. Jarosz, S.; Lewandowski, B. Synthesis and complexation properties towards the ammonium cation of aza-coronand analogues containing sucrose. Carbohydr. Res. 2008, 343, 965-969. [CrossRef] [PubMed]

11. Porwanski, S.; Dumarcay-Charbonnier, F.; Menuel, S.; Joly, J.-P.; Bulach, V.; Marsura, A. Bis- $\beta$-cyclodextrinyl- and bis-cellobiosyldiazacrowns: Synthesis and molecular complexation behaviors toward Busulfan anticancer agent and two basic aminoacids. Tetrahedron 2009, 65, 6196-6203. [CrossRef]

12. Pintal, M.; Kryczka, B.; Marsura, A.; Porwański, S. Synthesis of bis-cellobiose and bis-glucose derivatives of azacrown macrocycles as hosts in complexes with acetylsalicylic acid and 4-acetamidophenol. Carbohydr. Res. 2014, 386, 18-22. [CrossRef]

13. Pintal, M.; Kryczka, B.; Porwański, S. Stability of the Complexes of Bis-Saccharide Crown Ethers with p-Toluenesulfonamide. Heteroatom Chem. 2015, 26, 161-167. [CrossRef]

14. Ignaczak, A.; Porwański, S.; Szyszka, M. Deeper insight into the properties of the newly synthesized macrocycles as drug receptors-Some preliminary quantum chemical studies. New J. Chem. 2017, 41, 521-529. [CrossRef]

15. Rathjens, A.; Thiem, J. Synthesis of carbohydrate-based azamacrocycles by Richman-Atkins cyclisation. C. R. Chim. 2011, 14, 286-300. [CrossRef]

16. Rathjens, A.; Thiem, J. Carbohydrate-based aza-macrocycles by Richman-Atkins cyclization of glucopyranose precursors. Carbohydr. Res. 2017, 438, 18-25. [CrossRef]

17. Rathjens, A.; Thiem, J. Syntheses of anomerically bridged mannofuranosides and aza-macrocycles by Richman-Atkins cyclization. J. Carbohydr. Chem. 2016, 35, 397-411. [CrossRef]

18. Bakó, P.; Fenichel, L.; Tóke, L.; Czugler, M. Synthese und Komplexbildung von Kronenethern aus Methyl-4,6-O-benzyliden- $\alpha$-Dglucopyranosid. Liebigs Annalen Chemie 1981, 1163-1171. [CrossRef]

19. Bakó, P.; Fenichel, L.; Tóke, L. The complexing ability of crown ethers incorporating glucose. J. Incl. Phenom. Mol. 1993, 16, 17-23. [CrossRef]

20. Tóth, G.; Dietrich, W.; Bakó, P.; Fenichel, L.; Tőke, L. Reaction of methyl 2,3-anhydro-4,6-O-benzylidene- $\alpha$-D-allopyranoside with ethanolamine and 1,4,7,10-tetraoxa-13-azacyclopentadecane. Carbohydr. Res. 1987, 168, 141-145. [CrossRef]

21. Bakó, P.; Fenichel, L.; Tőke, L. Novel azacrown ethers incorporating sugars: Synthesis and complex formation. J. Chem. Soc. Perkin I 1989, 2514-2516. [CrossRef]

22. Bakó, P.; Tóke, L. Novel monoaza- and diazacrown ethers incorporating sugar units and their extraction ability towards picrate salts. J. Incl. Phenom. Mol. 1995, 23, 195-201. [CrossRef]

23. Bakó, P.; Czinege, E.; Bakó, T.; Czugler, M.; Tőke, L. Asymmetric C-C bond forming reactions with chiral crown catalysts derived from D-glucose and D-galactose. Tetrahedron Asymmetry 1999, 10, 4539-4551. [CrossRef]

24. Bakó, P.; Novák, T.; Ludányi, K.; Pete, B.; Tőke, L.; Keglevich, G. D-Glucose-based azacrown ethers with a phosphonoalkyl side chain: Application as enantioselective phase transfer catalysts. Tetrahedron Asymmetry 1999, 10, 2373-2380. [CrossRef]

25. Novák, T.; Bakó, P.; Keglevich, G.; Dobó, A.; Vékey, K.; Tőke, L. Synthesis of D-Glucose-based Azacrown Ethers with Phosphinoxidoalkyl Side Chains and Their Application to an Enantioselective Reaction. J. Incl. Phenom. Macro. 2001, 40, $207-212$. [CrossRef]

26. Rapi, Z.; Bakó, P.; Drahos, L.; Keglevich, G. Side-Arm Effect of a Methyl $\alpha$-D-Glucopyranoside Based Lariat Ether Catalysts in Asymmetric Syntheses. Heteroat. Chem. 2015, 26, 63-71. [CrossRef]

27. Nemcsok, T.; Rapi, Z.; Bagi, P.; Hou, G.Y.; Orbán, I.; Keglevich, G.; Bakó, P. Enantioselective cyclopropanation of conjugated cyanosulfones using carbohydrate-based crown ether catalysts. Tetrahedron 2020, 76, 130965. [CrossRef] 
28. Bakó, P.; Vízvárdi, K.; Bajor, Z.; Tőke, L. Synthesis and application in asymmetric synthesis of azacrown ethers derived from D-glucose. Chem. Commun. 1998, 1193-1194. [CrossRef]

29. Bakó, P.; Vízvárdi, K.; Toppet, S.; Van der Eycken, E.; Hoornaert, G.J.; Tőke, L. Synthesis, extraction ability and application in asymmetric synthesis of azacrown ethers derived from D-glucose. Tetrahedron 1998, 54, 14975-14988. [CrossRef]

30. Pham, T.S.; Rapi, Z.; Bakó, P.; Petneházi, I.; Stirling, A.; Jászay, Z. Enantioselective synthesis of substituted $\alpha$-aminophosphonates catalysed by d-glucose-based crown ethers: Pursuit of the origin of stereoselectivity. New J. Chem. 2017, 41, 14945-14953. [CrossRef]

31. Bakó, P.; Kiss, T.; Tőke, L. Chiral azacrown ethers derived from D-glucose as catalysts for enantioselective Michael addition. Tetrahedron Lett. 1997, 38, 7259-7262. [CrossRef]

32. Bakó, P.; Bajor, Z.; Tőke, L. Synthesis of novel chiral crown ethers derived from D-glucose and their application to an enantioselective Michael reaction. J. Chem. Soc. Perkin Trans I 1999, 3651-3655. [CrossRef]

33. Bakó, T.; Bakó, P.; Keglevich, G.; Bombicz, P.; Kubinyi, M.; Pál, K.; Bodor, S.; Makó, A.; Tőke, L. Phase-transfer catalyzed asymmetric epoxidation of chalcones using chiral crown ethers derived from D-glucose, D-galactose, and D-mannitol. Tetrahedron Asymmetry 2004, 15, 1589-1595. [CrossRef]

34. Rapi, Z.; Grün, A.; Keglevich, G.; Stirling, A.; Bakó, P. Synthesis of $\alpha$-D-galactose-based azacrown ethers and their application as enantioselective catalysts in Michael reactions. New J. Chem. 2016, 40, 7856-7865. [CrossRef]

35. Bakó, P.; Bakó, T.; Bisztray, K.; Szöllősy, Á.; Nagy, K.; Tőke, L. Synthesis, Extraction Ability and Application in an Asymmetric Synthesis of Azacrown Ethers Derived from D-Mannitol. J. Incl. Phenom. Macrocycl. 2001, 39, 247-251. [CrossRef]

36. Bakó, P.; Bakó, T.; Mészáros, A.; Keglevich, G.; Szöllősy, Á.; Bodor, S.; Makó, A.; Tőke, L. Phase Transfer Catalysed Asymmetric Epoxidation of Chalcones Using Chiral Crown Ethers Derived from D-Glucose and D-Mannose. Synlett 2004, 643-646. [CrossRef]

37. Bakó, P.; Makó, A.; Keglevich, G.; Kubinyi, M.; Pál, K. Synthesis of D-mannose-based azacrown ethers and their application in enantioselective reactions. Tetrahedron Asymmetry 2005, 16, 1861-1871. [CrossRef]

38. Makó, A.; Menyhárd, D.K.; Bakó, P.; Keglevich, G.; Tőke, L. Asymmetric epoxidation of substituted chalcones and chalcone analogues catalyzed by $\alpha$-D-glucose- and $\alpha$-D-mannose-based crown ethers. J. Mol. Struct. 2008, 892, 336-342. [CrossRef]

39. Makó, A.; Szöllősy, Á.; Keglevich, G.; Menyhárd, D.K.; Bakó, P.; Tőke, L. Synthesis of methyl- $\alpha$-D-glucopyranoside-based azacrown ethers and their application in enantioselective reactions. Monats. Chem. 2008, 139, 525-535. [CrossRef]

40. Szabó, T.; Rapi, Z.; Keglevich, G.; Szöllősy, Á.; Drahos, L.; Bakó, P. Synthesis of L-arabinose-based crown ethers and their applications as enantioselective phase transfer catalysts. ARKIVOC 2012, 36-48. [CrossRef]

41. Rapi, Z.; Bakó, P.; Keglevich, G.; Szöllősy, Á.; Drahos, L.; Hegedûs, L. Synthesis of ribo-hexopyranoside- and altrose-based azacrown ethers and their application in an asymmetric Michael addition. Carbohydr. Res. 2013, 365, 61-68. [CrossRef] [PubMed]

42. Rapi, Z.; Ozohanics, O.; Tóth, G.; Bakó, P.; Höfler, L.; Nemcsok, T.; Kánya, N.; Keglevich, G. Syntheses and complexing ability of $\alpha$-D-gluco- and $\alpha$-D-xylofuranoside-based lariat ethers. J. Incl. Phenom. Macro. 2016, 85, 19-32. [CrossRef]

43. Rapi, Z.; Nemcsok, T.; Pálvölgyi, Á.; Keglevich, G.; Grün, A.; Bakó, P. Synthesis of L-threitol-based crown ethers and their application as enantioselective phase transfer catalyst in Michael additions. Chirality 2017, 29, 257-272. [CrossRef]

44. Nemcsok, T.; Rapi, Z.; Keglevich, G.; Grün, A.; Bakó, P. Synthesis of D-mannitol-based crown ethers and their application as catalyst in asymmetric phase transfer reactions. Chirality 2018, 30, 407-419. [CrossRef]

45. Pálvölgyi, Á.; Rapi, Z.; Ozohanics, O.; Tóth, G.; Keglevich, G.; Bakó, P. Synthesis of alkyl $\alpha$ - and $\beta$-D-glucopyranoside-based chiral crown ethers and their application as enantioselective phase-transfer catalysts. Res. Chem. Intermed. 2018, 44, 1627-1645. [CrossRef]

46. Rapi, Z.; Nemcsok, T.; Bagi, P.; Keglevich, G.; Bakó, P. Synthesis of chiral crown ethers derived from D-galactose and their application in enantioselective reactions. Tetrahedron 2019, 75, 3993-4004. [CrossRef]

47. Nemcsok, T.; Rapi, Z.; Bagi, P.; Keglevich, G.; Bakó, P. Synthesis of xylal- and arabinal-based crown ethers and their application as asymmetric phase transfer catalysts. Chirality 2020, 32, 107-119. [CrossRef] [PubMed]

48. Bakó, P.; Fenichel, L.; Tőke, L. Synthesis and complex-forming properties of crown ethers incorporating glucuronic acid moieties. J. Incl. Phenom. Mol. 1996, 26, 321-330. [CrossRef]

49. Bakó, P.; Tőke, L.; Szöllősy, Á.; Bombicz, P. Asymmetric Michael addition of 2-nitropropane to a chalcone catalyzed by chiral crown ethers incorporating a D-glucose unit. Heteroatom Chem. 1997, 8, 333-337. [CrossRef]

50. Bakó, P.; Szöllősy, Á.; Bombicz, P.; Tőke, L. Asymmetric C-C Bond Forming Reactions by Chiral Crown Catalysts; Darzens Condensation and Nitroalkane Addition to the Double Bond. Synlett 1997, 291-292. [CrossRef]

51. Novák., T.; Tatai, J.; Bakó, P.; Czugler, M.; Keglevich, G.; Tőke, L. Asymmetric Michael Addition Catalyzed by D-Glucose-based Azacrown Ethers. Synlett 2001, 424-426. [CrossRef]

52. Bakó, T.; Bakó, P.; Szöllősy, Á.; Keglevich, G.; Czugler, M.; Tőke, L. Enantioselective Michael reaction of 2-nitropropane with substituted chalcones catalysed by chiral azacrown ethers derived from $\alpha$-D-glucose. Tetrahedron Asymmetry 2002, 13, 203-209. [CrossRef]

53. Bakó, T.; Bakó, P.; Báthori, N.; Keglevich, G.; Czugler, M.; Tatai, J.; Novák, T.; Parlagh, G.; Tőke, L. Enantioselective Michael addition of 2-nitropropane to chalcone analogues catalyzed by chiral azacrown ethers based on $\alpha$-D-glucose and D-mannitol. Tetrahedron Asymmetry 2003, 14, 1917-1923. [CrossRef] 
54. Makó, A.; Rapi, Z.; Drahos, L.; Szöllősy, Á.; Keglevich, G.; Bakó, P. Enantioselective Michael Addition of 2-Nitropropane to Substituted Chalcones and Chalcone Analogues Catalyzed by Chiral Crown Ethers Incorporating an $\alpha$-D-Glucose or an $\alpha$-D-Mannose Unit. Lett. Org. Chem. 2010, 7, 424-431. [CrossRef]

55. Jászay, Z.; Pham, T.S.; Németh, G.; Bakó, P.; Petneházi, I.; Tőke, L. Asymmetric Synthesis of Substituted $\alpha$-Amino Phosphonates with Chiral Crown Ethers as Catalysts. Synlett 2009, 1429-1432. [CrossRef]

56. Jászay, Z.; Tódor, I.; Rapi, Z.; Bakó, P.; Petneházi, I.; Tőke, L. Diethyl (cyanofluoromethyl)phosphonate: Application in catalytic enantioselective Michael additions. Phosphorus Sulfur 2017, 192, 659-664. [CrossRef]

57. Bakó, P.; Rapi, Z.; Keglevich, G.; Szabó, T.; Sóti, P.L.; Vigh, T.; Grün, A.; Holczbauer, T. Asymmetric C-C bond formation via Darzens condensation and Michael addition using monosaccharide-based chiral crown ethers. Tetrahedron Lett. 2011, 52, 1473-1476. [CrossRef]

58. Rapi, Z.; Démuth, B.; Keglevich, G.; Grün, A.; Drahos, L.; Sóti, P.L.; Bakó, P. Enantioselective Michael addition of malonates to aromatic nitroalkenes catalyzed by monosaccharide-based chiral crown ethers. Tetrahedron Asymmetry 2014, 25, 141-147. [CrossRef]

59. Bakó, P.; Rapi, Z.; Grün, A.; Nemcsok, T.; Hegedû́s, L.; Keglevich, G. Asymmetric Michael Addition of Malonates to Enones Catalyzed by an $\alpha$-D-Glucopyranoside-Based Crown Ether. Synlett 2015, 1847-1851. [CrossRef]

60. Rapi, Z.; Grün, A.; Nemcsok, T.; Hessz, D.; Kállay, M.; Kubinyi, M.; Keglevich, G.; Bakó, P. Crown ether derived from D-glucose as an efficient phase-transfer catalyst for the enantioselective Michael addition of malonates to enones. Tetrahedron Asymmetry 2016, 27, 960-972. [CrossRef]

61. Rapi, Z.; Nemcsok, T.; Grün, A.; Pálvölgyi, Á.; Samu, G.; Hessz, D.; Kubinyi, M.; Kállay, M.; Keglevich, G.; Bakó, P. Asymmetric cyclopropanation reactions catalyzed by carbohydrate-based crown ethers. Tetrahedron 2018, 74, 3512-3526. [CrossRef]

62. Itoh, T.; Shirakami, S. Synthesis of Chiral Azacrown Ethers Derived from $\alpha$-D-Glucose and Their Catalytic Properties on the Asymmetric Michael Addition. Heterocycles 2001, 55, 37-43. [CrossRef]

63. Rapi, Z.; Szabó, T.; Keglevich, G.; Szöllősy, Á.; Drahos, L.; Bakó, P. Enantioselective synthesis of heteroaromatic epoxyketones under phase-transfer catalysis using D-glucose- and D-mannose-based crown ethers. Tetrahedron Asymmetry 2011, 22, 1189-1196. [CrossRef]

64. Rapi, Z.; Bakó, P.; Keglevich, G.; Szöllősy, Á.; Drahos, L.; Botyánszky, A.; Holczbauer, T. Asymmetric phase transfer Darzens reactions catalyzed by D-glucose- and D-mannose-based chiral crown ethers. Tetrahedron Asymmetry 2012, 23, 489-496. [CrossRef]

65. Makó, A.; Rapi, Z.; Keglevich, G.; Szöllősy, Á.; Drahos, L.; Hegedûs, L.; Bakó, P. Asymmetric epoxidation of substituted chalcones and chalcone analogues catalyzed by $\alpha$-D-glucose- and $\alpha$-D-mannose-based crown ethers. Tetrahedron Asymmetry 2010, 21, 919-925. [CrossRef] 